\title{
SOMETHING ORDINARY TO SOMETHING NAVY- EXPLORING INFLUENCER ARIELLE CHARNAS' USE OF PARASOCIAL INTERACTION TECHNIQUES ON INSTAGRAM
}

\author{
by \\ Lesley Shiner \\ BA, Western University, 2019 \\ A MRP presented to Ryerson University \\ in partial fulfillment of the requirements for the degree of Master of Professional \\ Communication in the program of Faculty of Communication and Design
}

Toronto, Ontario, Canada, 2020

(C) Lesley Shiner, 2020 


\section{AUTHOR'S DECLARATION FOR ELECTRONIC SUBMISSION OF A MAJOR RESEARCH PAPER}

I hereby declare that I am the sole author of this MRP. This is a true copy of the MRP, including any required final revisions.

I authorize Ryerson University to lend this MRP to other institutions or individuals for the purpose of scholarly research.

I further authorize Ryerson University to reproduce this MRP by photocopying or by other means, in total or in part, at the request of other institutions or individuals for the purpose of scholarly research.

I understand that my MRP may be made electronically available to the public. 


\begin{abstract}
The purpose of this research paper is to explore ideas that may highlight why Instagram users may be interested in following the lives and daily activities of social media influencers on Instagram. Social media influencers have been defined as "independent third party endorsers who have developed sizeable social networks by sharing details about their personal lives, experiences, and opinions publicly through texts, pictures, videos” (Ki \& Kim, 2019, p. 905). Research also suggests that if successful, influencers can become "opinion leaders who communicate with a sizeable social network of people following them" (Boerman, 2020, p. 199). Arielle Charnas is a New York City fashion influencer with over one million followers on Instagram, and she will be used as a case to study alongside parasocial interaction to explore how, as an influencer, she incorporates techniques from this theory to establish a connection with her followers. This MRP supports research that proposes that the two established parasocial interaction techniques of perceived interactivity and openness "should increase feelings of parasocial interaction" (Labrecque, 2014, p. 136). Moreover, the analysis of Arielle's Instagram supports the concept that the development of feelings of a parasocial relationship can be enhanced when "media presentations resemble interpersonal interaction" (Perse \& Rubin, 1989, p. 60).
\end{abstract}




\section{Acknowledgments}

I would like to sincerely thank Dr. Wendy Freeman for her continual support and valuable advice throughout the entire writing process. Her guidance and academic expertise were integral to the successful completion of this MRP. 


\section{Table of Contents}

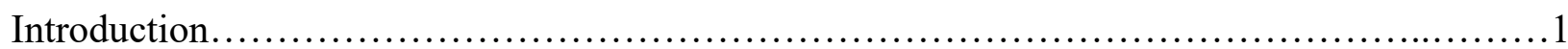

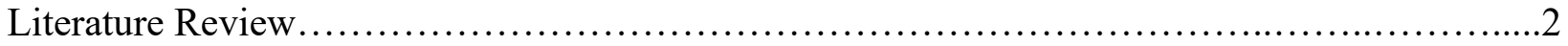

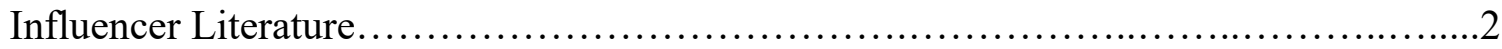

Parasocial Interaction Theory...............................................

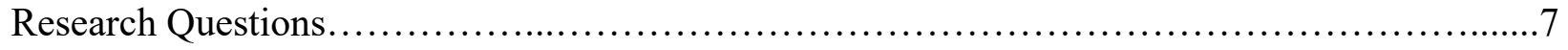

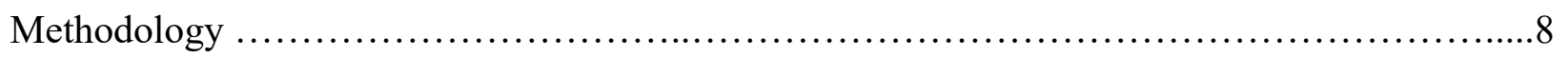

Data Collection...............................................................

Data Analysis............................................................11

Findings/Discussion ........................................................... 17

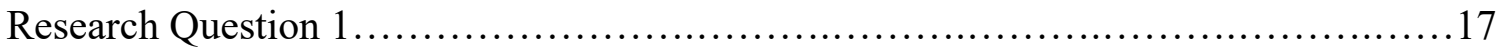

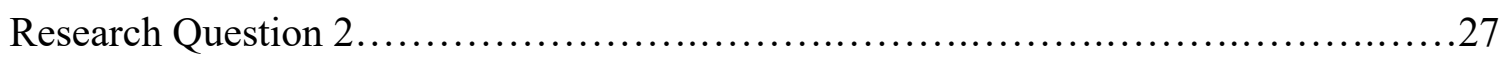

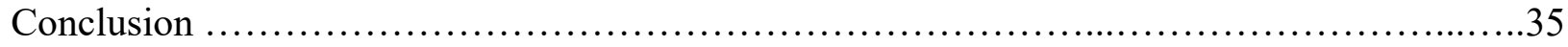

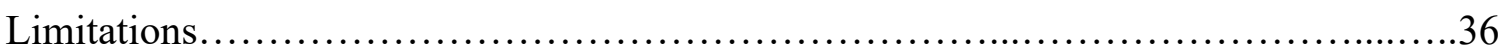

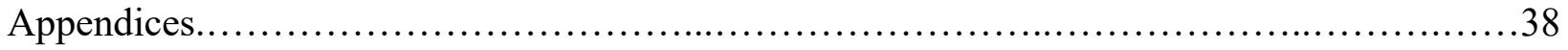

References......................................................................... 41 


\section{List of Tables}

Table 1: Total Posts Collected and Analyzed..........................................11

Table 2: Preliminary Codes- Parasocial Interaction................................... 11

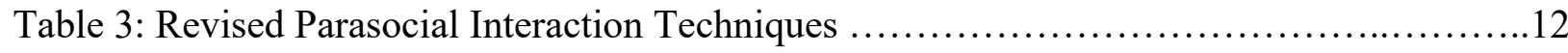

Table 4: Parasocial Interaction Techniques Total...................................... 13

Table 5: Influencer Techniques ................................................ 15

Table 6: Influencer Techniques Total............................................ 15

Table 7: Combination of Parasocial and Influencer Techniques Total.......................16

Table 8: Perceived Interactivity Techniques Total.................................... 17

Table 9: Self-Promotion Techniques Total........................................21

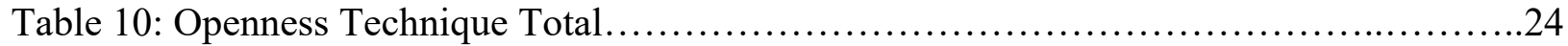

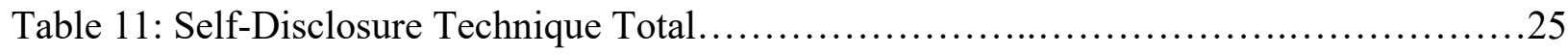

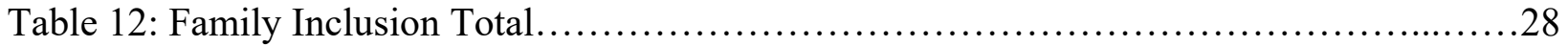

Table 13: Interacting with Other Brands Total........................................29 


\section{List of Figures}

Figure 1: Open-Ended Question in Caption...........................................20

Figure 2: Directly Engaging Followers and Something Navy Promotion ....................38

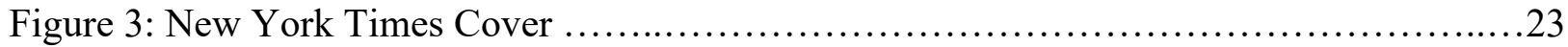

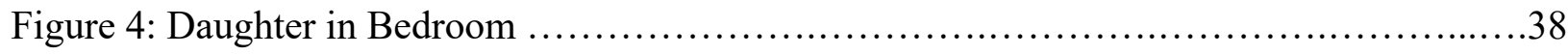

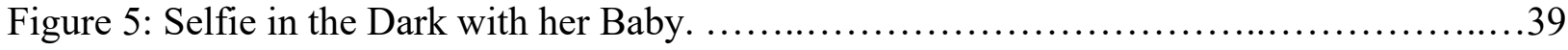

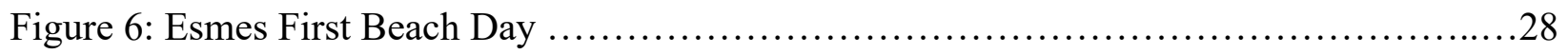

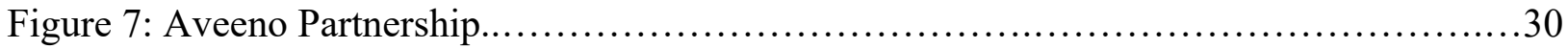

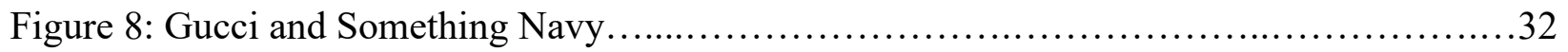

Figure 9: \#snmirrormoment............................................................. 


\section{List of Appendices}

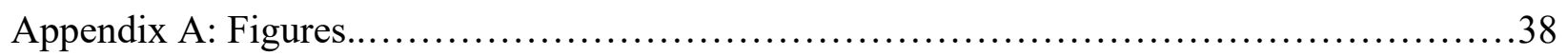

Appendix B: Title and Date of Post, Likes and Comments..............................40 



\section{Introduction}

This paper will discuss Instagram influencers, specifically how Instagram as a social media platform allows an ordinary individual to construct a personal brand for themselves and promote it online. The concept of purposefully constructing an identity to present in front of others is not a new phenomenon, and humans have always put thought into how they present themselves. Erving Goffman (1956) discusses the mask that humans design for themselves explaining that "this mask represents the conception we have formed of ourselves- the role we are striving to live up to- this mask is our truer self, the self we would like to be" (p. 12). Instagram allows for an individual to promote a self online that "really is more attractive" (Baym, 2015, p. 146). This is because face-to-face interactions are not required between a creator and their followers and Instagram allows one to form a personal brand and produce content in line with that desired image. In their discussion of self-branding, Hearn and Schoenhoff (2015) argue that "the self-brander works to generate a kind of celebrity value simply by cultivating a notable image-persona" (p. 202) They note that if successful, there is the possibility for select individuals to shift simply from self-branding, to cultivating an identity that attracts countless followers. These celebrities on Instagram are referred to as social media influencers, who are individuals with a large following that have knowledge on particular topics and document details about their personal lives on Instagram both "visually and verbally" (Ki \& Kim, 2019, pp. 905906). Unlike celebrities featured in magazines or on TV, influencers document themselves in their natural state and can even interact with followers by responding to comments or direct messages (Hearn \& Schoenhoff, 2015, p. 204). This interactive feature that Instagram offers, allows for a perceived intimate connection between an influencer and follower to be developed (Labrecque, 2014). As a result of this, parasocial interaction theory will be used as a lens to 
inquire into the potential strategies that the popular New York City influencer Arielle Charnas uses to attract millions to her Instagram platform. Previously known on Instagram as "Something Navy", Arielle, who currently has 1.3 million followers on Instagram, started her blog in 2009 and in 2018 turned her Instagram name into a full namesake label and lifestyle brand ("About", 2020, para. 1). Arielle designed the Something Navy brand "for the everyday icon", and comments that her blog is an "online destination which is carefully curated" to provide her followers "with inspiring, engaging, and relatable content" (“About”, 2020, para. 1). Arielle Charnas's Instagram will be examined alongside parasocial interaction to explore how, as an influencer, she incorporates techniques from this theory to establish a connection with her followers.

\section{Literature Review}

\section{Influencer Literature}

Instagram is the "fastest growing social network site globally", and the most popular platform for influencer marketing (Sheldon \& Bryant, 2016, p. 89). Influencer marketing is the increasingly popular strategy of using social media influencers as an advertising technique

(Boerman, 2020, p. 199). Instagram is an application meant to be downloaded on mobile phones "compatible with the iOS and Android mobile operating systems" (Marwick, 2015, p. 142). The app is a social media platform made for uploading photographs or videos, and users can "manipulate them using filters, share them with other Instagram users, and comment on or like the photos of others (Marwick, 2015, p. 142). Following other accounts on Instagram is "unidirectional" and Marwick (2015) notes that Instagram does not require permission to follow certain accounts, making it an environment that encourages "fans or curious strangers", unlike Facebook which promotes friends, through "mutual following” (p. 143). 
Freberg, Graham, McGaughey, and Freberg's (2011) state that social media influencers, "represent a new type of independent third party endorser who shape audience attitudes through blogs, tweets, and the use of other social media" (p. 90). The Interactive Advertising Bureau (IAB) defines social media influencers as individuals who have "the potential to create engagement, drive conversation and/or sell products/services with the intended target audience" (Childers, Lemon, \& Hoy, 2019, p. 258). When brands collaborate with influencers, they become "brand ambassadors" and produce content by incorporating the brand into their pictures or captions, or by reposting the brands own content or "being part of larger advertising campaigns and events" (Boerman, 2020, p. 199). Similarly, in Ki and Kim’s (2019) study which analyzes a consumer's desire to mimic influencers, they agree that they are independent third party endorsers who "have developed sizeable social networks by sharing details about their personal lives, experiences, and opinions publicly through texts, pictures, videos" (p. 905). Boerman (2020) defines social media influencers as "opinion leaders who communicate with a sizeable social network of people following them" (p. 199). There is no set list in regards to the attributes a social media influencer must possess, but a dominant theme in the literature focuses on them being a source of credibility, especially for "niche based" influencers that focus on the specific needs and interests of their followers (Daniel, Jackson, \& Westerman, 2018, p. 102). The relationship that influencers build with their followers is essential to their success, especially when they are advertising a product or brand partnership. This is because their followers can confirm their intimate connection with the influencer by "supporting the circulation and sales of commodities" they endorse (Berryman \& Kavka, 2017, p. 309). Brands continue to shift from traditional advertising strategies, and instead utilize influencers to promote their products, and Childers, Lemon, and Hoy (2019) confirm that "consumers are much more likely to positively 
perceive and react to a message that comes from a trusted source, versus an advertiser's sponsored post (p. 258). Boerman (2020) discusses the need for an influencer to disclose to their followers when they are engaging in commercial relationships with a brand. To ensure influencers partake in this disclosure, Instagram has a "standardized built-in disclosure" that is located at the top of an Instagram post for users to fill in if they are being paid by a company to post certain content (Boerman, 2020, p. 199).

Pittman and Reich (2016) conducted a study on social media use and the feeling of loneliness, discovering that image-based platforms like Instagram, "confer to their users a significant decrease in self-reported loneliness" (p. 164). They propose that images have the ability to "facilitate social presence", meaning that when one views an image, they get the sense that they are "communicating with an actual person instead of an object" (Pittman \& Reich, 2016, p. 164). Instagram has the ability to upload both images and videos, and Pittman and Reich (2016) advance that videos where the viewer can hear one's voice, are more likely "to signal the brain that a friend is really there" (p. 164). Even with necessary disclosure, influencer endorsements are still likely to be seen as "highly credible electronic word of mouth" due to the way they are "seamlessly woven into the daily narratives influencers post on their Instagram accounts" (Cauberghe, Hudders \& De Veirman, 2017, 798). This paper will investigate this idea and explore how certain influencers are able to develop a "sizeable social network of people following them" by examining these concepts using the parasocial interaction theory (Boerman, 2020, p. 199). This theory which will be reviewed in the following section, is useful for looking into the relationship between influencer and follower because the theory began by studying the relationship between viewers and television personalities on screen. 


\section{Parasocial Interaction Theory}

The term parasocial interaction was developed by Horton and Wohl (1956) and the theory outlines the "seeming face-to face relationship between spectator and performer" (p. 215). They discuss the concept of intimacy within this relationship and propose that it is an illusion because "the relationship between the persona and any member of his audience is inevitably onesided, and reciprocity between the two can only be suggested" (1956, p. 217). Perse and Rubin (1989) build on Horton and Wohl's ideas of television viewers and characters on screen and understand parasocial interaction to be revolving around "vicarious interaction" rather than "actual interaction" (p. 60). It was discovered that when the personas on screen would "act informally", it allowed viewers to forget that the "action [was] taking place in a television studio (Perse \& Rubin, 1989, p. 60). They advance that "viewers feel that they know and understand the persona in the same intimate way they know and understand flesh-and-blood friends" and that the persona on screen is similar to members of the viewers social circle (Perse \& Rubin, 1989, p. 60). Stern, Russel and Russel (2007), also study parasocial relationships on television, and explore the idea of characters in a show acting as "surrogate friends" (p. 26). The authors explore "vicarious interaction" like Perse and Rubin and explain surrogate friends as viewers having "vicarious participation in characters lives", as a way to complete a gap they may have in their own life (Stern, Russel \& Russel, 2007, p. 27). Purse and Rubin (1989) propose that when the audience views the persona on screen, "a sense of conversational give-and-take often emerges" and Dibble, Hartmann and Rosaen (2016) suggest that this conversational nature "is strongest when the media performer bodily addresses the viewer through the camera" (p. 21). Similarly, Stephens, Hill and Bergman (1996) predicted that interactive technology would allow for greater opportunities of forming parasocial relationships, specifically the "feelings of friendship and 
intimacy on the viewer's part-with remote "personae"' (p. 194). Labrecque (2014) discusses the modern role of parasocial interaction in social media environments and confirms Stephens, Hill and Bergman's prediction that the development of it does not only happen within traditional mass media. Her research asserts that parasocial interaction can also be produced "through messages in an online environment that are designed to bring the viewer closer to a mediated persona, such as a brand or celebrity" (Labrecque, 2014, p. 135). However, Labrecque (2014) highlights the fact that although the internet has the ability to produce two-way communication between a persona on screen and an audience, these conversations can still appear as one-way conversations. She gives the example of unidentifiable brand representatives responding to consumers, "leaving no clues to determine who is actually responding on behalf of the brand while supporting the perception that the message is coming directly from the brand" (Labrecque, 2014, p. 135). Labrecque (2014) defines this perception as "perceived interactivity", which she explains is the state when "the viewer not only becomes aware of the persona but also develops a sense that the persona seems aware of the viewer" (p. 136). Lee and Watkins (2016) also explore modern parasocial interaction online, but unlike Horton and Wohl that defined the actors on screen as "spectator and performer", they define these actors as "media personalities and media users" (p. 5754). Lee and Watkins (2016) comment that when parasocial interaction occurs "media users seek advice from media personalities as if they were friends", which is a current perspective on parasocial interaction that will be explored throughout this paper (p. 2).

This MRP examines the Instagram practices of Arielle Charnas. Arielle began her career in 2011 posting pictures of her daily outfits to her Instagram, and in 2018 transformed Something Navy, which was her original Instagram name, into a lifestyle and clothing brand. Arielle's millions of followers suggest that she has been successful as an Instagram influencer in attracting 
Instagram users to follow her heavily documented lifestyle, and the two following questions relating to parasocial interaction theory will more specifically address what the research will aim to discover.

\section{Research Questions}

The research questions of this study are the following:

1. What techniques, according to parasocial interaction theory, does Arielle use to communicate with her followers and how does she tend to use them?

2. Are there any noticeable patterns in the ways that Arielle exhibits specific parasocial interaction techniques alongside certain types of influencer techniques? 


\section{Methodology}

Throughout the course of ten years, Arielle has become a "leader in the influencer space", and continues to grow her "digitally-native, lifestyle brand" (“About”, 2020, para. 1). In 2016, Arielle posted a video of herself applying a skin care mask to her Snapchat, and within 24 hours of the video being uploaded "she was responsible for the sale of 502 masks, or $\$ 17,565$ worth of product...equal to $\$ 123,000$ in sales in a week, $\$ 527,000$ in a month or almost $\$ 6.4$ million in a year" (Strugatz, 2016). To further validate her influence, in 2018 Arielle launched a collection with Nordstrom which became, "the retailer's most successful partnership ever- driving an estimated $\$ 5$ million in single-day sales and beating past collaborations with Beyonce and Rihanna" (Curotto, 2018). Arielle states that the goal of both her blog and her Instagram are to show followers how to "purchase Something Navy approved products", reveal brands and services that she loves, and to "uncover thought-provoking features, and bring to life other voices in [her] sphere of influence” (“About”, 2020, para. 1). An Architectural Digest article showcasing Arielle's New York City home describes her Flatiron-neighborhood apartment as being "equal parts enviable and approachable, much like her online persona" (Izon, 2019, para. $1)$.

Arielle was selected as the case study for this research paper exploring the potential uses of parasocial interaction techniques between an influencer and follower, because she started blogging her everyday outfits as an extra-curricular activity, with no previous fame or following, and has "steadily risen to become one of the most well-known social media influencers in the world" (Izon, 2019, para. 1). Arielle does not only post fashion content, but also shares intimate moments of her marriage, her two daughters, her lifestyle and travel destinations. Arielle has grown to become a meso-influencer, which is a term used to describe influencers that have 
"10,000 to a million followers and a national visibility" (Boerman, 2020, p. 202). Although Arielle still has an active blog, her Instagram is the only social media platform that will be analyzed for this paper because she is the most active on it. Additionally, Instagram allows for visual and textual communication through posting photos with captions alongside them, which will display how she communicates to her followers through visual imagery and verbal messaging.

Qualitative research focuses on words and images rather than numbers, and Bryman and Bell (2016) state that this method "allows categories to emerge out of data analysis and recognizes the significance of the context in which items appear" (p. 403). Moreover, utilizing qualitative content analysis allows "inductive category development" which can occur after engaging in the data, which allows the "categories and names for categories to flow from the data" (Hsieh \& Shannon, 2005, p. 1279). A qualitative content analysis was conducted to investigate Arielle's Instagram use in order to discover if and how she has evolved her communication strategies to connect with followers. It is necessary to examine both mediums of image and text. This style of analysis will be beneficial in determining a potential strategy in the type of content Arielle chooses to post as an influencer.

\section{Data Collection}

Arielle created her Instagram in 2011 and is active on this platform every day except for the extremely rare occasion where she does not post. For the scope of this research, Arielle's posts began to be collected starting on September $24^{\text {th }}, 2018$, which was the day of her first launch of her Something Navy line with Nordstrom, until her post on April $2^{\text {nd }}$, 2020, the day the data for this paper began to be analyzed. Since Arielle posts on Instagram every day, only one day of the week was selected to examine the posts Arielle uploaded on that day. This created an 
organized and reasonably sized sample of selecting posts from the same day each week. Friday's were selected as the day to collect data, because on Friday's Arielle is able to post about the previous weekday's activities, or the upcoming weekend ahead. This specific time frame was chosen because during this period Arielle was busy as a wife, mother and very active in her influencing career with the establishment of her Nordstrom partnership.

For each post, the visual image posted to her Instagram feed and the text in the caption were captured and the number of likes and comments were recorded. Looking at the number of likes and comments demonstrates which of her posts are most highly engaged with by her followers. She mostly posts images, but sometimes Arielle posts videos, and in that case the number of views of the video were recorded as well. Each Instagram post was screenshotted from her Instagram page and saved to an Excel spreadsheet with the date it was posted, and the number of likes and comments recorded in the following rows.

Posts that Arielle uploaded to her Instagram on Friday's were collected from the years 2018, 2019, and 2020. The breakdown of posts by month totaled to 33 posts from 2018, 123 posts from 2019, and 14 posts from 2020, which equaled to 170 posts in total. After collecting and recording all 170 posts (see Table 1 below) from each Friday in the designated time frame, it became clear that to be able to more deeply analyze each post to look for patterns in techniques, one post from every Friday would be selected as she sometimes posted four or five Instagram's per day. If an image was accompanied by a caption that just had an emoji or a tagged brand, a post with a longer caption was selected. From the 170 posts that were collected every Friday, each were preliminarily coded identifying techniques, and within that coding one post from every Friday with the broadest range of techniques was chosen for the next deeper round of 
coding. As describes in Table 1 below, the sample size was then reduced to 14 posts in 2018, 48 posts in 2019, and 11 posts in 2020 for a total of 73 posts analyzed.

\section{Table 1}

Total Posts Collected and Analyzed

\begin{tabular}{lcc}
\cline { 2 - 3 } Year & & \\
\cline { 2 - 3 } & Collected & Analyzed \\
\hline 2018 & 33 & 14 \\
2019 & 123 & 48 \\
2020 & 14 & 11 \\
Total & 170 & 73 \\
\hline
\end{tabular}

\section{Data Analysis}

The posts were then sorted and labeled by number in chronological order, along with the year, moth, and the number of post it was within that month. The organized data was analyzed with specific codes that were produced from previously implemented codes in Labrecque (2014), Chen (2016), and Chung and Cho’s (2017) literature exploring parasocial relationships and social media. These four codes are displayed and described in Table 2.

\section{Table 2}

Preliminary Codes- Parasocial Interaction

Category

Description

Perceived Interactivity Deals with elements such as the speed of the response to consumers and "being dependent on the user's perception of taking part in a two-way communication with a mediated persona" (Labrecque, 2014, p. 136).

Self-Promotion "The act of seeking to be viewed as competent by touting an individual's abilities and accomplishments" (Chen, 2016, p. 246).

Openness The act of revealing information to a viewer which aims to "build intimacy and trust" (Labrecque, 2014, p. 136). 
Self-Disclosure

Posting "seemingly honest expressions of emotion... uploads of selfies of themselves and their families, and inside information, [making] social media interactions feel personal, intimate, and inviting (Chung \& Cho, 2017 p. 484).

After analyzing the posts with the above preliminary codes, it became evident that more specific sub codes with more detailed explanations needed to be formed to be better applied to Arielle's content, as the original codes were too broad to assist in identifying patterns. As a result of this realization, the explanations of the codes were expanded, still using definitions from previous literature. Table 3 exhibits the codes with their sub codes.

Table 3

Revised Parasocial Interaction Techniques

\section{Category}

\begin{tabular}{|c|c|}
\hline & Description \\
\hline $\begin{array}{l}\text { Perceived Interactivity- } \\
\text { Direct Engagement }\end{array}$ & $\begin{array}{l}\text { Viewer develops a sense that the persona seems aware of the } \\
\text { viewer... "based on creating an impression that the persona is } \\
\text { listening and responding directly to the audience with cues } \\
\text { within the message itself" (Labrecque, 2014, p. 136). }\end{array}$ \\
\hline $\begin{array}{l}\text { Perceived Interactivity- } \\
\text { Maintaining connection }\end{array}$ & $\begin{array}{l}\text { Maintaining the user's perception of "taking part in two-way } \\
\text { communication with a mediated persona" (Labrecque, 2014, } \\
\text { p. 136). }\end{array}$ \\
\hline Self-Promotion- Career & $\begin{array}{l}\text { "The act of seeking to be viewed as competent by touting an } \\
\text { individual's abilities and accomplishments" (Chen, 2016, p. } \\
\text { 246). }\end{array}$ \\
\hline $\begin{array}{l}\text { Self-Promotion- Something } \\
\text { Navy (personal brand) }\end{array}$ & $\begin{array}{l}\text { Posting "seemingly honest expressions of emotion....uploads } \\
\text { of selfies of themselves and their families, and inside } \\
\text { information, [making] social media interactions feel personal, } \\
\text { intimate, and inviting (Chung \& Cho, } 2017 \text { p. 484). }\end{array}$ \\
\hline Openness & $\begin{array}{l}\text { The act of revealing information to a viewer which aims to } \\
\text { "build intimacy and trust... [giving] the viewer the sense that } \\
\text { he or she has gained inside information about aspects of the } \\
\text { persona ...creates a feeling as if they know the persona on a } \\
\text { more personal level" (Labrecque, 2014, p. 136). }\end{array}$ \\
\hline
\end{tabular}


Self-Disclosure

"Confessional messaging" that can shift from the superficial to revealing "intimate, hidden, or personal ideas" (Chung \& Cho, 2017 p. 483).

Table 4 presents examples of each parasocial interaction technique code, and the total amount of times each of the codes appeared in the designated time frame of posts between September $24^{\text {th }}, 2018$ until April $2^{\text {nd }}, 2020$. The number of times the code appeared, was divided by the total number of posts (73), to calculate what percentage of the time Arielle applied each of the codes to her Instagram's. The total percentage does not add up to 100 because in some cases more than one code was applicable to the content of the post, resulting in some posts being coded multiple times.

\section{Table 4}

Parasocial Interaction Techniques Total

Category

\begin{tabular}{|c|c|c|c|}
\hline & Description & Example & $\begin{array}{l}\text { Posts } \\
\mathrm{n}=73\end{array}$ \\
\hline $\begin{array}{l}\text { Perceived } \\
\text { Interactivity- } \\
\text { Direct } \\
\text { Engagement }\end{array}$ & $\begin{array}{l}\text { Viewer develops a sense that the } \\
\text { persona seems aware of the } \\
\text { viewer... "based on creating an } \\
\text { impression that the persona is } \\
\text { listening and responding directly } \\
\text { to the audience with cues within } \\
\text { the message itself" (Labrecque, } \\
\text { 2014, p. 136). }\end{array}$ & $\begin{array}{l}\text { "New partnership: excited } \\
\text { to be working with } \\
\text { @mango to bring you some } \\
\text { more super cute affordable } \\
\text { looks! \#mango \#ad }\end{array}$ & $25(34 \%)$ \\
\hline $\begin{array}{l}\text { Perceived } \\
\text { Interactivity- } \\
\text { Maintaining } \\
\text { Connection }\end{array}$ & $\begin{array}{l}\text { Maintaining the user's perception } \\
\text { of "taking part in two-way } \\
\text { communication with a mediated } \\
\text { persona" (Labrecque, 2014, p. } \\
\text { 136). }\end{array}$ & $\begin{array}{l}\text { "Back in my winter clothes } \\
\text { and couldn't be happier" }\end{array}$ & $36(49 \%)$ \\
\hline
\end{tabular}




\begin{tabular}{|c|c|c|c|}
\hline $\begin{array}{l}\text { Self- } \\
\text { Promotion- } \\
\text { Career }\end{array}$ & $\begin{array}{l}\text { "The act of seeking to be viewed } \\
\text { as competent by touting an } \\
\text { individual's abilities and } \\
\text { accomplishments" (Chen, 2016, } \\
\text { p. 246) }\end{array}$ & $\begin{array}{l}\text { "Our first cover and feature } \\
\text { is officially out! Thank you } \\
\text { @minimagazine for this } \\
\text { very special opportunity, I } \\
\text { will cherish these photos } \\
\text { forever. }\end{array}$ & $17(23 \%)$ \\
\hline $\begin{array}{l}\text { Self- } \\
\text { Promotion- } \\
\text { Something } \\
\text { Navy } \\
\text { (Personal } \\
\text { Brand) }\end{array}$ & $\begin{array}{l}\text { Promoting/Referring to } \\
\text { Something Navy- any time her } \\
\text { personal brand is tagged or } \\
\text { mentioned }\end{array}$ & $\begin{array}{l}\text { "Excited to announce the } \\
\text { new category I'm launching } \\
\text { in February under the } \\
\text { @somethingnavy umbrella! } \\
\text { TSWIM!" }\end{array}$ & $21(28 \%)$ \\
\hline Openness & $\begin{array}{l}\text { The act of revealing information } \\
\text { to a viewer which aims to "build } \\
\text { intimacy and trust... [giving] the } \\
\text { viewer the sense that he or she } \\
\text { has gained inside information } \\
\text { about aspects of the persona } \\
\text {...creates a feeling as if they } \\
\text { know the persona on a more } \\
\text { personal level" (Labrecque, } \\
\text { 2014, p. 136). }\end{array}$ & "madly in love. & $31(42 \%)$ \\
\hline $\begin{array}{l}\text { Self- } \\
\text { Disclosure }\end{array}$ & $\begin{array}{l}\text { "Confessional messaging" that } \\
\text { can shift from the superficial to } \\
\text { revealing "intimate, hidden, or } \\
\text { personal ideas" (Chung \& Cho, } \\
2017 \text { p. 483). }\end{array}$ & $\begin{array}{l}\text { "Fun day, } \\
\text {. } \\
\text { \#whocanrelate" } z^{2} \text { "motherhood }\end{array}$ & $7(9 \%)$ \\
\hline
\end{tabular}

After applying the above codes to the data, it seemed necessary to create categories that reflect prominent elements discussed in literature surrounding influencers to better understand how Arielle acts in her role as an influencer. The following codes displayed in Table 5 emerged after looking at the data and were placed beside the codes relating to parasocial interaction to observe if certain elements of influencer behaviour affected when and how Arielle uses certain parasocial interaction techniques. 


\section{Table 5}

Influencer Techniques

Category

\begin{tabular}{ll}
\cline { 2 - 2 } $\begin{array}{l}\text { Kids/Family Members } \\
\text { Featured }\end{array}$ & $\begin{array}{l}\text { Description } \\
\text { member appear in a picture or are referred to in a caption. }\end{array}$ \\
Other Brands Tagged & $\begin{array}{l}\text { Any time another brand (other than Something Navy) is tagged } \\
\text { on the post or in the caption. }\end{array}$ \\
\#Ad or Paid Partnership & $\begin{array}{l}\text { If the hashtag \#ad or \#paidpartnership is indicated anywhere in } \\
\text { the post, revealing she is sponsoring a brand. }\end{array}$ \\
\hline
\end{tabular}

Table 6 exhibits the total amount of times each of the influencer techniques appeared in the designated time frame of posts between September $24^{\text {th }}, 2018$ until April $2^{\text {nd }}, 2020$. The number of times the code appeared, was divided by the total number of posts (73), to calculate what percentage of the time Arielle used each technique within the data.

\section{Table 6}

Influencer Techniques Total

Category

Description Posts

Kids/Family

Members Featured

Any instance her children, husband, or extended family $28(38 \%)$ member appear in a picture or are referred to in a caption

Other Brands

Tagged

Any time another brand (other than Something Navy)

$51(69 \%)$ is tagged on the post or in the caption

\#Ad or Paid

If the hashtag \#ad or \#paidpartnership is indicated

$10(13 \%)$

Partnership anywhere in the post, revealing she is sponsoring a brand 
In order to examine how often Arielle paired a technique of parasocial interaction with an influencer technique, each post was coded to see how the two categories of codes interacted and connected. Table 7 displays the total amount of times Arielle used a parasocial interaction technique alongside an influencer technique. However, the number of times a parasocial interaction technique appeared was not divided by the total number of posts (73), it was divided by the total number of posts the three influencer codes appeared in. As Table 7 presents, Arielle featured her kids and family in 28 posts, tagged other brands in 51 posts, and revealed an ad or paid partnership in 10 posts. Again, the percentage totals will not equal to $100 \%$, as each post exhibited multiple techniques.

\section{Table 7}

Combination of Parasocial and Influencer Techniques Total

Parasocial Interaction

Techniques

\begin{tabular}{llll}
\cline { 2 - 4 } & $\begin{array}{l}\text { Kids/Family } \\
\text { Members Featured } \\
\text { Total }(\mathrm{n}=28)\end{array}$ & $\begin{array}{l}\text { Other Brands } \\
\text { Tagged Total } \\
(\mathrm{n}=51)\end{array}$ & $\begin{array}{l}\text { \#Ad or Paid } \\
\text { Partnership } \\
\text { Total }(\mathrm{n}=10)\end{array}$ \\
\hline $\begin{array}{l}\text { Perceived Interactivity- } \\
\text { Direct Engagement }\end{array}$ & $7(25 \%)$ & $14(27 \%)$ & $5(50 \%)$ \\
$\begin{array}{l}\text { Perceived Interactivity- } \\
\text { Maintaining Connection }\end{array}$ & $19(67 \%)$ & $28(54 \%)$ & $3(30 \%)$ \\
$\begin{array}{l}\text { Self-Promotion- Career } \\
\begin{array}{l}\text { Self-Promotion- Something } \\
\text { Navy (Personal Brand) }\end{array}\end{array}$ & $2(6 \%)$ & $18(35 \%)$ & $10(100 \%)$ \\
Openness & $25(89 \%)$ & $11(21 \%)$ & $1(10 \%)$ \\
Self-Disclosure & $5(15 \%)$ & $23(45 \%)$ & $6(60 \%)$ \\
\hline
\end{tabular}




\section{Findings/Discussion}

During the process of analyzing the visual image and textual caption of Arielle's Instagram posts, the following research question guided the analysis.

\section{Research Question 1: What techniques according to parasocial interaction theory does Arielle use to communicate with her followers and how does she tend to use them?}

Multiple strategies of parasocial interaction that have been studied in previous research, have been successful in proposing that certain techniques have the ability to increase feelings of parasocial interaction (Labrecque (2014), Chen (2016), and Chung \& Cho (2017)). Research also shows that the creation of feelings of parasocial interaction have the ability to be produced through messages in online environments that are designed to "bring the viewer closer to a mediated persona, such as a brand or celebrity" (Labrecque, 2014, p. 135). The development of the feelings of parasocial interaction can be increased when the performer on screen "acts informally" and the sense of that relationship can be enhanced when "media presentations resemble interpersonal interaction" (Perse \& Rubin, 1989, p. 60). After conducting a detailed analysis of the sampled data, it became clear that Arielle exhibited all four codes in differing amounts throughout her Instagram's within the selected time frame of posts

Perceived interactivity was found to be the most frequently used technique by Arielle, and the understanding of the term "perceived interactivity" was derived from Labrecque's (2014) work on exploring how parasocial interaction impacts brand relationships on social media. Table 8 is a breakdown of the total amount of times the code of perceived interactivity appeared in the sampled data.

\section{Table 8}

Perceived Interactivity Techniques Total 


\begin{tabular}{lll} 
& & \\
\cline { 2 - 3 } Category & Description & $\begin{array}{l}\text { Posts } \\
\mathrm{n}=73\end{array}$ \\
\hline $\begin{array}{l}\text { Perceived Interactivity- } \\
\text { Direct Engagement }\end{array}$ & $\begin{array}{l}\text { Viewer develops a sense that the persona seems } \\
\text { aware of the viewer... "based on creating an } \\
\text { impression that the persona is listening and } \\
\text { responding directly to the audience with cues within } \\
\text { the message itself" (Labrecque, 2014, p. 136). }\end{array}$ & $25(34 \%)$ \\
Perceived Interactivity- & $\begin{array}{l}\text { Maintaining the user's perception of "taking part in } \\
\text { Maintaining connection }\end{array}$ & $36(49 \%)$ \\
& \begin{tabular}{l} 
(Labrecque, 2014, p. 136). \\
\hline
\end{tabular} & \\
\hline
\end{tabular}

Table 8 displays that Arielle used the technique of perceived interactivity in the form of maintaining a connection with her followers, $15 \%$ more of the time than when she directly addressed them. When she does not address her followers directly, the manner that she speaks to them is less formal and more casual than when she directly engages with them. One common device that Arielle practices is using techniques of perceived interactivity on posts that refer to Something Navy. In a post from October 2018, Arielle is promoting her newly designed sweatshirts, and captions the post, saying “Finallyyyyy, sweaters!!!! @somethingnavy :)" (4.18.10.2). She is not blatantly advertising her clothes or pressuring her followers to order her products, but by spelling "finally" in the dragged out way that she did is a technique that can emphasize how long her followers may have been waiting for this day. This post of the Something Navy sweaters received 42.6K likes and 674 comments, which is an extremely high amount as there are only 10 posts in the data that received over $40 \mathrm{~K}$ likes, and 600 comments. Marwick and Boyd's (2011) study of celebrity practice on Twitter provides a way of understanding why the post might have been so popular. Their study discovered that "spelling and grammatical errors in social media messages" are a way to make audiences feel closer to a celebrity (p. 149). They found that Tweets that were personal, or that contradicted "the 
stereotype of the overly managed 'celebrity' account" made the celebrity appear more authentic than those who posted perfectly curated Tweets (Marwick \& Boyd, 2011, p. 149).

Another way in which perceived interactivity was identified can be found when Arielle mentions Something Navy and includes open-ended questions within her captions. Sokolova and Kefi (2019) discuss the idea that online bloggers are similar to celebrities featured in traditional media such as television or film in the sense that they may be successful in creating the appearance of a "bidirectional relationship" (p. 4). Arielle's use of the technique of open-ended questions may make the relationship between her and her followers appear more real that "illusory" (Sokolova \& Kefi, 2019, p. 4). Perceived interactivity in the form of direct engagement, demonstrates how Arielle makes it very clear when she wants to speak directly to her followers by addressing them in first person, using words like "you". Chung \& Cho (2017) contend that "the use of the first-person ("I" and "we") ...in social media messages from celebrities make their audiences feel closer to them" (p. 483). Creating feelings of parasocial interaction on a social media platform is different than on traditional media such as television because the persona actually has the ability to respond back to a follower (Labrecque, 2014, p. 135). However, because Arielle has over one million followers, the likelihood that she would actually respond to all her comments is highly unlikely. Nevertheless, the fact that she purposely opens the conversation to them is a message cue that "can be used to preserve the feelings of a two-way interaction between the persona and the brand" which Labrecque (2014) argues can foster parasocial interaction (p. 136). Labrecque (2014) states multiple devices that support the development of parasocial interaction, one of those devices being the "direct address of viewers (visually and verbally)", and she comments that this direct conversation "intensifies feelings" of parasocial interaction (p. 136). Although she only included open-ended questions in 6 of her 
captions $(8 \%)$, it is a strategy that allows Arielle's viewers to become involved, without her having to respond back to them. An example of this is when Arielle posted in her new sleepwear line, captioning the post, "who is ordering the silk pajamas on Wednesday?" or when she posted a mirror selfie asking her followers "how would you wear these boots?" (8.18.11.2 \& 27.19.3.5). Both of these caption's casual tones almost seem to mirror a texting conversation between friends, and the tactic of asking an open-ended question is a successful way to manufacture the perception of a two way conversation because of the "message cues that indicate responsiveness and listening" (Labrecque, 2014, p. 136). There are far too many comments for Arielle to reply to each one of them, but her followers have the freedom to respond to the question she is proposing to them in the caption.

\section{Figure 1}

\section{Open-Ended Question in Caption}
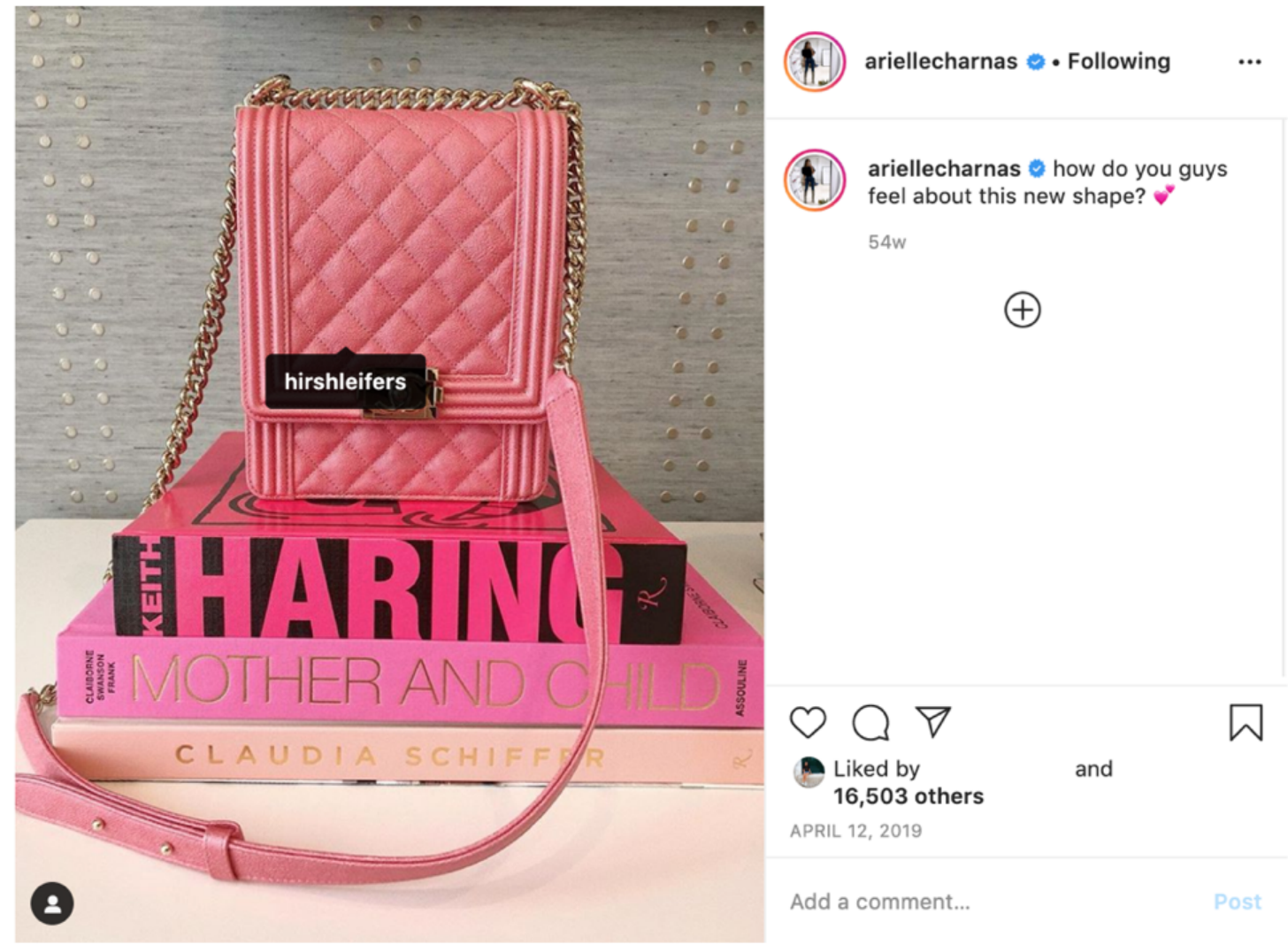
Figure 1 is another example of Arielle placing an open-ended question in her caption, and this post received 410 comments. Arielle received over 400 comments on 13 posts (17\%) only. Perse \& Rubin's (1989) statement which suggests that involving followers can enhance parasocial interaction may help to explain why this simple Instagram of a purse was one of Arielle's top 13 most highly commented on posts (p. 60). Both forms of perceived interactivity appear in posts that were coded as exhibiting self-promotion techniques $43 \%$ of the time, which could allow her followers to feel included in her brand activities.

\section{Table 9}

Self-Promotion Technique Totals

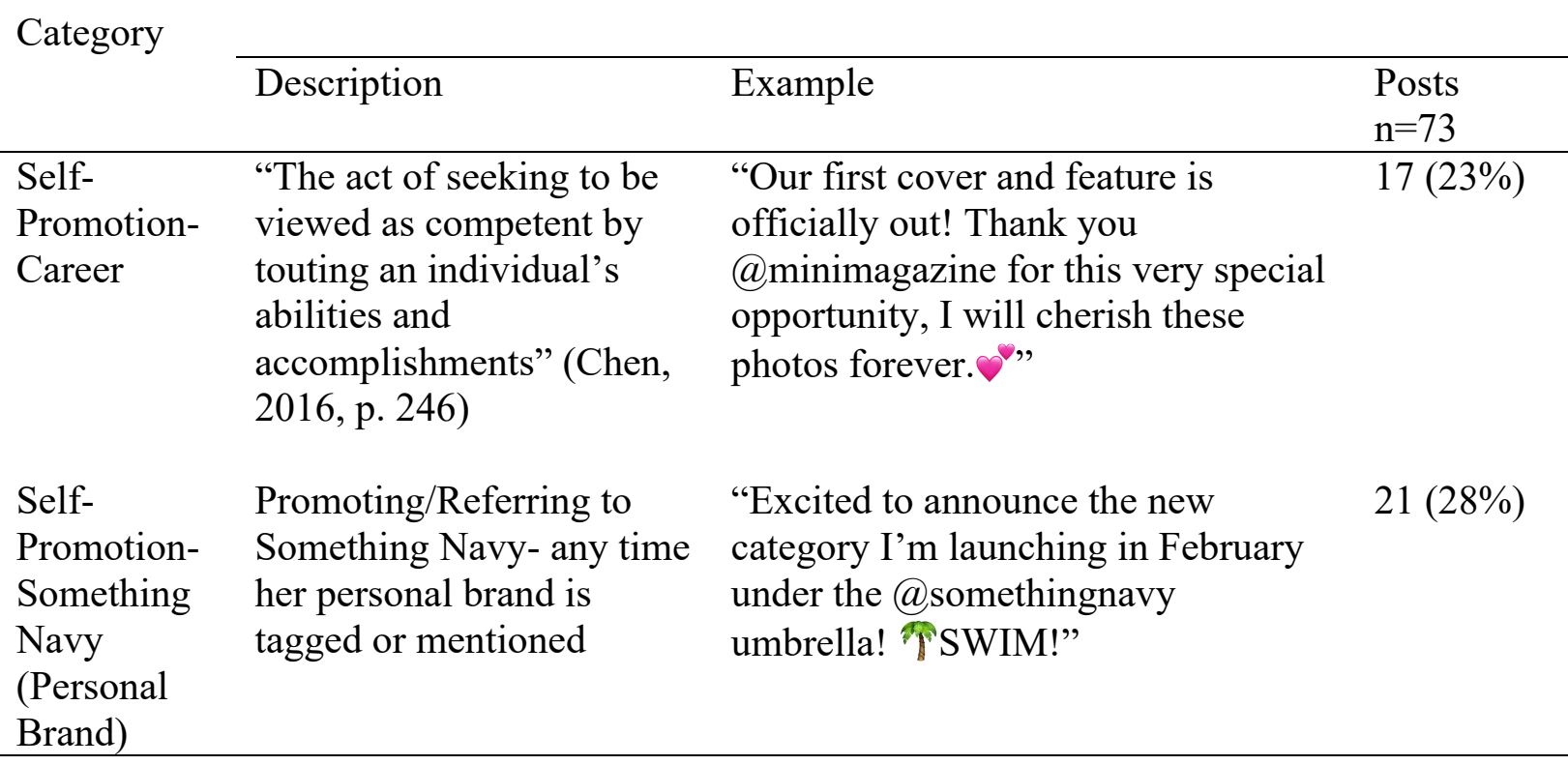

Table 9 (above) further reveals how often Arielle engages in techniques of selfpromotion, and whether those instances were promoting her influencer career or her brand. Chen (2016) discusses forming parasocial relationships on YouTube, and notes that one common strategy of digital self-presentation is self-promotion. Self-promotion is not only attempting to make oneself seem competent by promoting their skills or accomplishments but requires the 
"framing of performances" (Chen, 2016, p. 246). The framing of performances can suggest that a persona on screen such as a YouTuber or influencer selects "ideal or perfect gestures as well as behaviors to be shot", meaning that the content they choose to post to maintain their image is not random, but rather carefully manufactured (Chen, 2016, p. 246). Arielle's Instagram is dedicated to showcasing her brand and her lifestyle, so this is a significant code to include to observe how Arielle goes about publicizing her brand and career achievements. As displayed above in Table 9. Arielle promoted her brand 5\% more than her influencer career, and the manner in which she conducted each style of promotion differed.

Firstly, as previously mentioned, when promoting Something Navy, she addressed her followers directly by engaging them in the caption. Not only did she address her followers, but in this specific instance displayed in Figure 2 in Appendix A, she attributed the design of the top she is wearing to her followers. The visual of this Instagram is just a simple selfie of the back of her top, but the first sentence of the caption where she says "thank you all for helping me design this piece to wear this weekend" is another example displaying how she relies on perceived interactivity as a way to recognize her followers $(60.19 .12 .2)$. It is very clear when Arielle uses the technique of self-promotion for her personal brand, because as exemplified in Figure 2 in Appendix A, she always tags Something Navy in the caption or on the post. This Instagram Arielle uploaded to promote her clothing brand falls in line with Chen's (2016) definition of framed performances, because she mentions her followers in 19 out of the $21(90 \%)$ posts that refer to Something Navy, suggesting it could be a framed, purposeful behaviour. Whether or not Arielle listens to their design suggestions, she makes it seem like she does, and her language validates her followers and makes them feel included in every step of the production. However, when she expresses an accomplishment related to her influencer career, Arielle only mentions 
her followers in $8(47 \%)$ of the 17 posts. This means Arielle includes her followers in some way $43 \%$ more when she promotes her own brand.

\section{Figure 3}

\section{New York Times Cover}
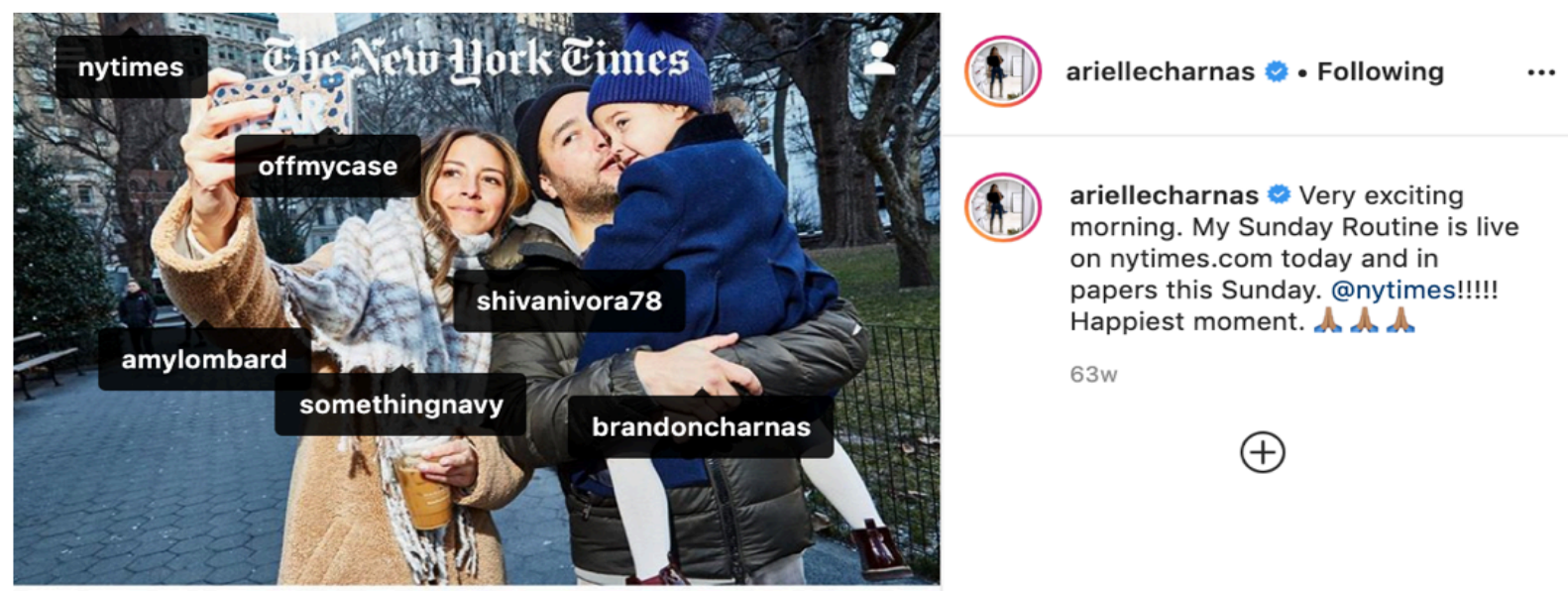

Ms. Charnas with her husband, Brandon Charnas, and their older daughter, Ruby. Amy Lombard for The New York Times

SUNDAY ROUTINE

\section{How Arielle Charnas, Fashion Influencer, Spends Her Sundays}

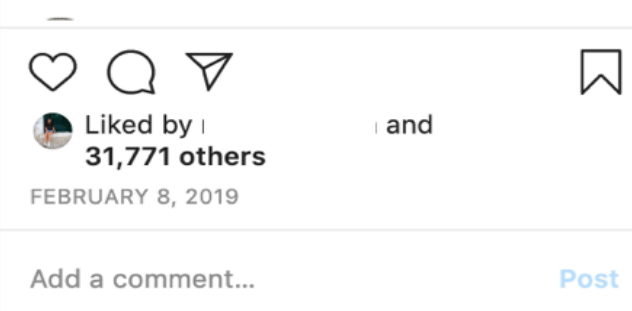

This Instagram promoting her first feature in the New York Times is an example demonstrating when Arielle does not mention her followers in a post associated with another established company that is furthering her career as an influencer. Although Arielle does not refer to her followers in this case, as evident in Figure 3,13\% of the time when she is revealing a career milestone, she tags Something Navy on the post. Another prominent theme when sharing a career milestone is how Arielle always recognizes the company that gave her that opportunity by tagging them in the caption and tags any other relevant brands that helped create the 
Instagram. The most visible difference in the use of the two codes of self-promotion is Arielle's inclusivity with her followers in her posts promoting Something Navy, and the emphasis on other brands in career related posts.

The code of openness was included in the coding table to measure the instances where Arielle seemed to reveal information to her followers that would work to build intimacy in the relationship with them. Labrecque (2014) compares parasocial interaction as being "akin to a friendship", and when the persona on screen engages in openness in communication it is as if they are "breaking the fourth wall" (p. 136). In his study of parasocial interaction and television, Auter (1992) focused on the idea of the fourth wall and how it affects the degree of intimacy that can be built between a "program character" and the viewer. He defined the technique of breaking the fourth wall as "stepping out of character to address the audience" (Auter, 1992, p. 176). This technique can be applied to the practice of influencers to measure how they step away from the image of themselves they are promoting and reveal personal information to foster a closer relationship. The example of Figure 4 in Appendix $A$ is representative of the sort of Instagrams Arielle posts which were coded as demonstrating openness. Her captions were short and to the point, but clearly filled with love and adoration for her daughters, and this was expressed by including heart emojis. She posts unedited photos of them in intimate settings like their bedroom, which makes the Instagram look candid, and not framed to be perfect. Labrecque (2014) comments that viewers absorbed in parasocial interaction relationships "express desire for learning personal details about the persona", and Arielle posts pictures of her daughters weekly, documenting countless moments of their childhoods (p. 136).

\section{Table 10}

Openness Technique Total 


\begin{tabular}{|c|c|c|c|}
\hline \multicolumn{4}{|l|}{ Category } \\
\hline & Description & Example & $\begin{array}{l}\text { Posts } \\
n=73\end{array}$ \\
\hline Openness & $\begin{array}{l}\text { The act of revealing information to a } \\
\text { viewer which aims to "build intimacy } \\
\text { and trust... [giving] the viewer the } \\
\text { sense that he or she has gained inside } \\
\text { information about aspects of the } \\
\text { persona ...creates a feeling as if they } \\
\text { know the persona on a more personal } \\
\text { level" (Labrecque, } 2014, \text { p. } 136 \text { ). }\end{array}$ & $\begin{array}{l}\text { "madly in love. } \\
\text { "Happy Friday! So excited } \\
\text { for the weekend and my } \\
\text { baby's birthday party!!! }\end{array}$ & $31(42 \%)$ \\
\hline
\end{tabular}

Openness was coded when Arielle would use expressive language and punctuation to describe how she was feeling, and this language was clearly different than when she used an unemotional tone, as displayed in the examples in Table 10. The fourth category in the coding method is the technique of self-disclosure, which also has to do with expressive language but differs from openness in the sense that the information revealed may not only be to build a more intimate relationship with followers. The practice of self-disclosure delivers "seemingly honest expressions of emotion, and the sharing of highly opinionated statements on various topics" and expresses "highly confessional messaging" that is clearly different from their everyday content (Chung \& Cho, 2017, p. 483). Chung and Cho (2017) express that social media has a "selfdisclosing nature" and because of this the interactions on social media platforms can enhance perceived intimacy and create the feelings of a parasocial relationships (p. 484). Openness was used 33\% more than self-disclosure throughout her posts, as self-disclosure only appeared in $9 \%$ of her posts as indicated in Table 11, making it Arielle's least used technique of parasocial interaction.

\section{Table 11}

Self-Disclosure Technique Total 


\begin{tabular}{llll} 
Category & \multicolumn{2}{c}{} \\
\cline { 2 - 4 } & Description & Example & $\begin{array}{l}\text { Posts } \\
\text { n=73 }\end{array}$ \\
\hline Self- & $\begin{array}{l}\text { "Confessional } \\
\text { Disclosure }\end{array}$ & $\begin{array}{l}\text { messaging" that can } \\
\text { shift from the } \\
\text { superficial to revealing } \\
\text { "intimate, hidden, or } \\
\text { today but instead I'm in my backyard still in } \\
\text { personal ideas" (Chung } \\
\text { \& Cho, 2017 p. 483). }\end{array}$ & $\begin{array}{l}\text { pajamas bc we were up all night with ruby } \\
\text { (who is finally napping). I shot this the other } \\
\text { day with anna when she was out here :)" }\end{array}$ \\
\hline
\end{tabular}

It is evident when Arielle uses this code because the caption and visual image of the post are completely opposite of the content she typically shares. As displayed in Figure 5 in Appendix $A$, Arielle is posting from the very intimate setting of her bedroom, in the dark, in her pajamas with no makeup on and her sleeping baby on top of her. The example featured in Figure 5 in Appendix A demonstrates a clear shift in Arielle's typical posts both "visually and verbally" because her feed is usually filled with bright and happy pictures of her kids, and this type of raw visual content was not found in any other post in the data (Chung \& Cho, 2017, p. 483).

Although Arielle did not rely on this technique often, there was a noticeable pattern when she did choose to include it. Five out of the seven times she used self-disclosure, the post was related to her family. Out of the other two posts that did not include her family, one had to do with career struggles, where she admits to being bullied for posing on the internet ten years ago before blogging was a mainstream activity. The other had to do with Arielle being hungover, and because of that she wore bright pink underwear under white pants without realizing they were see through. One significant post utilizing self-disclosure, shows Arielle's nanny unwrapping a birthday gift she gave her, of a Yves Saint Laurent backpack. This video was viewed 352610 times and has 962 comments, which makes it Arielle's second most commented on post from the data. In the caption of this Instagram she writes honestly about the help she receives, and how 
her nanny helps her "raise her babies" and allows her to "do all the things she wants to do"

(64.20.1.2). Other than this post, Arielle never reveals or speaks about her nanny, which appears to make it a "confessional" post (Chung \& Cho, 2017 p. 483).

It is clear that Arielle exhibits all four of the techniques of parasocial interaction that were used as codes to categorize her posts. However, the technique of perceived interactivity and openness were exhibited the most in her Instagram's. Arielle used both of these techniques to include her followers in the posts and offer them intimate information about her life. It is necessary to examine if she combined these devices that have the ability to enhance feelings of parasocial interaction with common influencer practices, as that may highlight strategies that could suggest how influencers maintain a following. As a result, the second and final research question shifts to focus on which techniques Arielle tends to rely on more and aims to discover the ways she exhibits and combines specific techniques of parasocial interaction with influencer practices.

\section{Research Question 2: Are there any noticeable patterns in the ways that Arielle exhibits} specific parasocial interaction techniques alongside certain types of influencer techniques?

There are evident patterns in the data exemplifying the way that Arielle combined techniques of parasocial interaction with common influencer practices that have the ability to "shape audience attitudes" (Freberg et al., 2010, p. 1). The first identifiable trend was for Arielle to include her family in posts where she exhibits the techniques of self-disclosure and openness. Table 12 demonstrates that Arielle referred to her family in $38 \%$ of the sampled posts and appeared to use the technique of openness in $89 \%$ of those family related posts, proposing that posts that are related to her family appear more intimate. 
Table 12

Family Inclusion Total

\begin{tabular}{|c|c|c|}
\hline \multirow{2}{*}{ Category } & & \\
\hline & Description & $\begin{array}{l}\text { Posts } \\
n=73\end{array}$ \\
\hline $\begin{array}{l}\text { Kids/Family } \\
\text { Members Featured }\end{array}$ & $\begin{array}{l}\text { Any instance her children, husband, or extended } \\
\text { family member appear in a picture or are referred to } \\
\text { in a caption }\end{array}$ & $28(38 \%)$ \\
\hline
\end{tabular}

A symbol as small as a heart emoji was coded as openness because there was a clear distinction in the type of posts that she chose to place hearts in the caption, to those that she did not. Out of the $38 \%$ of times that she tagged her family, she also tagged clothing brands in $25 \%$ of the $38 \%$ of those posts, as presented in Figure 6.

\section{Figure 6}

\section{Esmes First Beach Day}
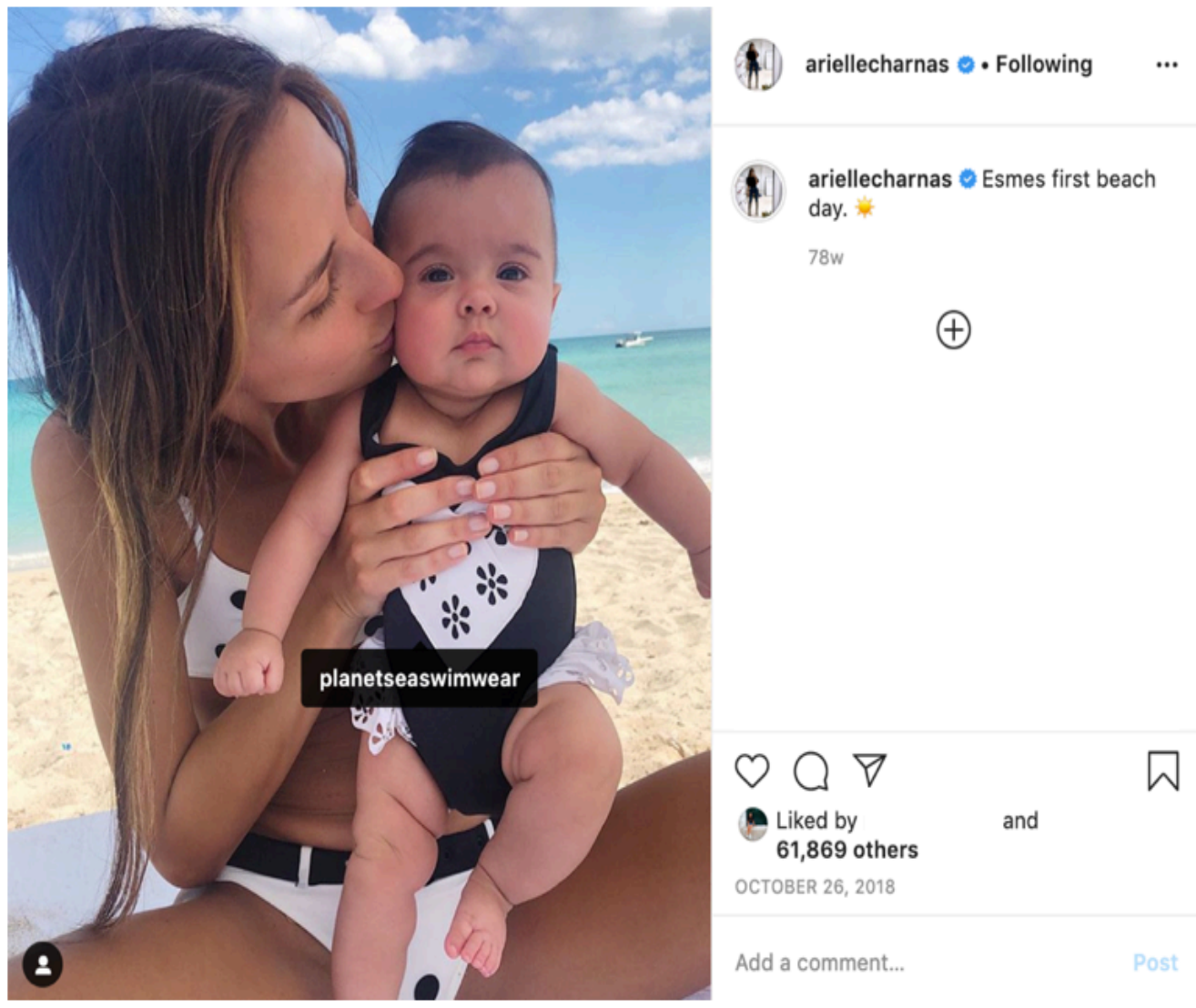
During a moment as personal as Arielle's baby's first day at the beach, as she announced in the caption of her Instagram in Figure 6, she still tagged the brand of her baby's bathing suit. The Instagram showcased in Figure 6 received $61.8 \mathrm{~K}$ likes, and 807 comments. This response is reflective of the volume of engagement Arielle acquired when posting with her family, as $80 \%$ of Arielle's most liked Instagram's from the sampled time frame included her family. It is possible that her followers could view her precious children and loving husband and crave that for themselves, or potentially feel like they know her children just from witnessing constate footage of their childhood that Arielle posts to her Instagram. This idea can be supported by Stern, Russel and Russel's (2007) study, that investigates parasocial relationships in relation to television, and explores the idea of characters in a show acting as "surrogate friends" (p. 26). The authors explain the notion of surrogate friends as viewers having "vicarious participation in characters' lives to fill gaps in one's own life - and relating to characters as if they were real friends" (Stern, Russel \& Russel, 2007, p. 27).

A dominant them in influencer literature is exploring the marketing abilities of Instagram and specifically how influencers are becoming more successful than traditional advertising strategies (Boerman, 2020). As displayed in Table 13, Arielle tags brands in her posts $69 \%$ of the time, but only participates in paid partnerships $13 \%$ of the time.

\section{Table 13}

Interacting with Other Brands Total

\begin{tabular}{llc} 
Category & \multicolumn{2}{c}{ Posts } \\
\cline { 2 - 3 } & Description & $51(69 \%)$ \\
\hline $\begin{array}{l}\text { Other Brands } \\
\text { Tagged }\end{array}$ & $\begin{array}{l}\text { Any time another brand (other than Something Navy) is } \\
\text { tagged on the post or in the caption }\end{array}$ & \\
\#Ad or Paid & $\begin{array}{l}\text { If the hashtag \#ad or \#paidpartnership is indicated anywhere } \\
\text { Partnership }\end{array}$ & $10(13 \%)$ \\
\hline
\end{tabular}


It is explicit when Arielle is partnering with a brand because somewhere on the post, she will use the hashtag of \#ad or \#paidpartnership, which indicates that she is getting paid for advertising that brand or product. Social media influencers must disclose when they are engaging in a paid partnership, because in 2017 the Federal Trade Commission (FTC) made it an obligation for influencers to "disclose commercial relationships" (Boerman, 2020, p. 199). There are only 10 instances from the sampled posts where Arielle indicates that an Instagram is an ad or a paid partnership. Every one of these posts is accompanied by a long and descriptive caption, and 9 out of the 10 posts incorporate the parasocial interaction techniques of openness and perceived interactivity. It is evident that Arielle always pairs heartfelt captions with paid partnership posts, and $50 \%$ of these posts refer to her children or family in some way.

\section{Figure 7}

\section{Aveeno Partnership}
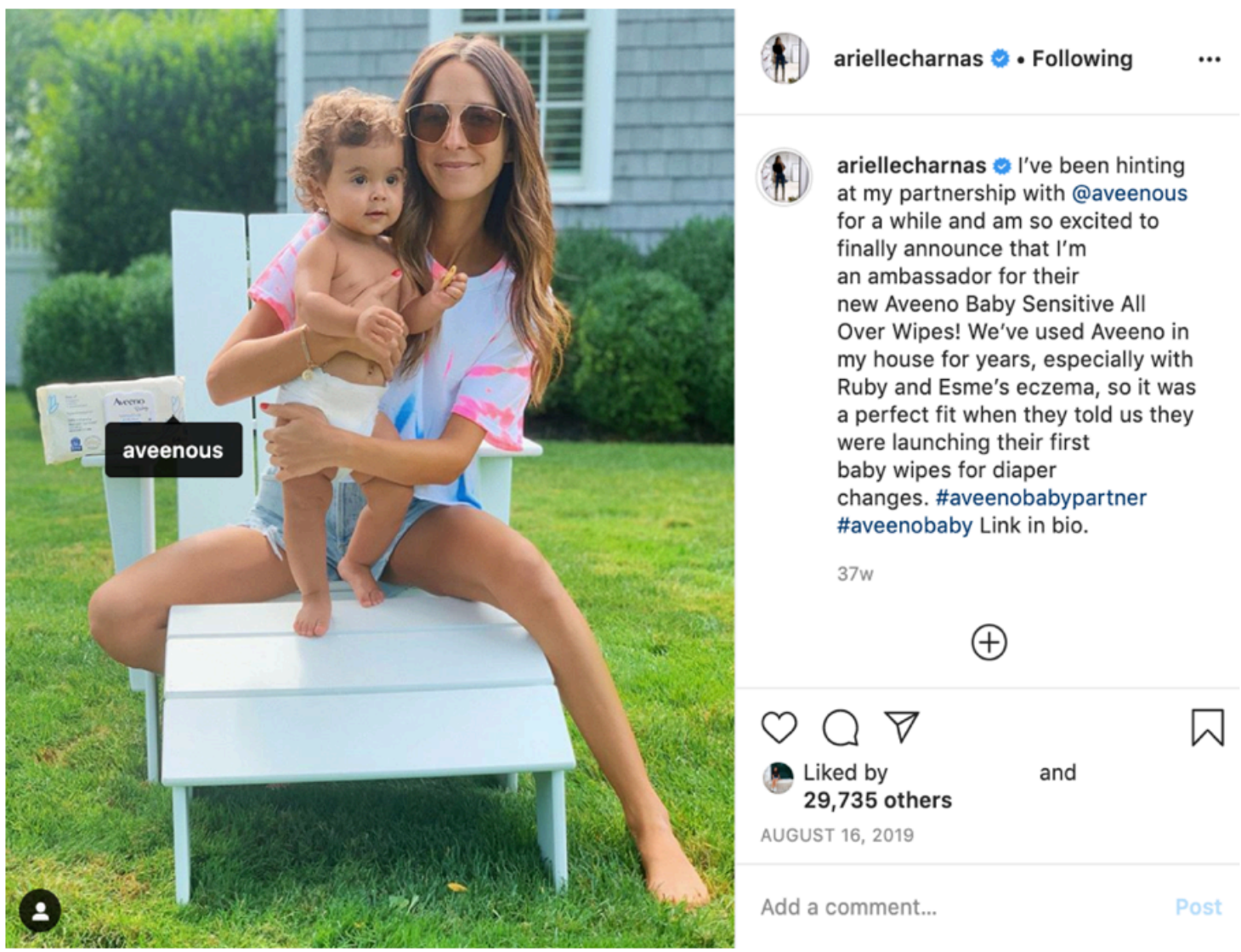
Figure 7 displays the use of both openness and perceived interactivity within a paid partnership post, which is a noticeable pattern demonstrating how Arielle combines the use of parasocial interaction techniques with an influencer technique. In the caption, Arielle writes that "we've used Aveeno in my house for years, especially with Ruby and Esme's eczema, so it was a perfect fit when they told us they were launching their first baby wipes for diaper changes" (45.19.8.3). When Arielle discusses how the product enhances her and her family's lives, it makes it appear as if Arielle truly uses those products in her own home. A similar example that exhibits Arielle's application of openness to a paid partnership post is her Instagram advertising her Volvo SUV. In the caption she reveals that "having a car in the city has been so helpful with...doctor visits, drop offs and pick-ups from school when its freezing out, rides uptown to the grandparents and into Brooklyn for the siblings" (12.18.12.2). Arielle does not merely pose in her car and disclose the paid partnership, but lets her followers know how she uses the product to improve her life. It is apparent that Arielle relies on the parasocial interaction techniques of openness and perceived interactivity when creating these posts, through strategies like personalizing the caption and relating it back to intimate information about her children and lifestyle.

Arielle tags brands other than Something Navy in $69 \%$ of her posts without mentioning that they are a paid partnership. Marwick (2015) discusses a form of microcelebrity, which includes a specific "visual self-presentation strategy", that allows regular people to attract a following by emulating "the tropes and symbols of traditional celebrity culture" (p. 139). The most popular symbol of celebrity culture is displaying hierarchies of luxury such as "glamorous self-portraits, designer goods, or luxury cars" (Marwick, 2015, p. 139). Arielle often replicates traditional symbols of luxury and this is especially evident when she tags specific hotels she is 
vacationing at. On her vacations, she does not always reveal the hotel she is at, so when she does purposely place the name of the hotel in the location tab, it seems to be intentional. An example of this is when she announced the new Something Navy swimwear line and tagged the Four Seasons Hotel in Surfside Florida as the location. Arielle posts other Instagram's from Florida, but not all of them have the location tagged, so it is an active choice to share exactly where she is when she does tag her location. Another instance where Arielle discloses the name of the hotel she is staying at is in St. Barts, one of the most luxurious tropical travel destinations, that attracts billionaires year round (Brunner, 2007). In addition to hotels, Figure 8 is an example of Arielle tagging the well-established luxury brand Gucci, in post where she is wearing a Something Navy sweater.

\section{Figure 8}

Gucci and Something Navy

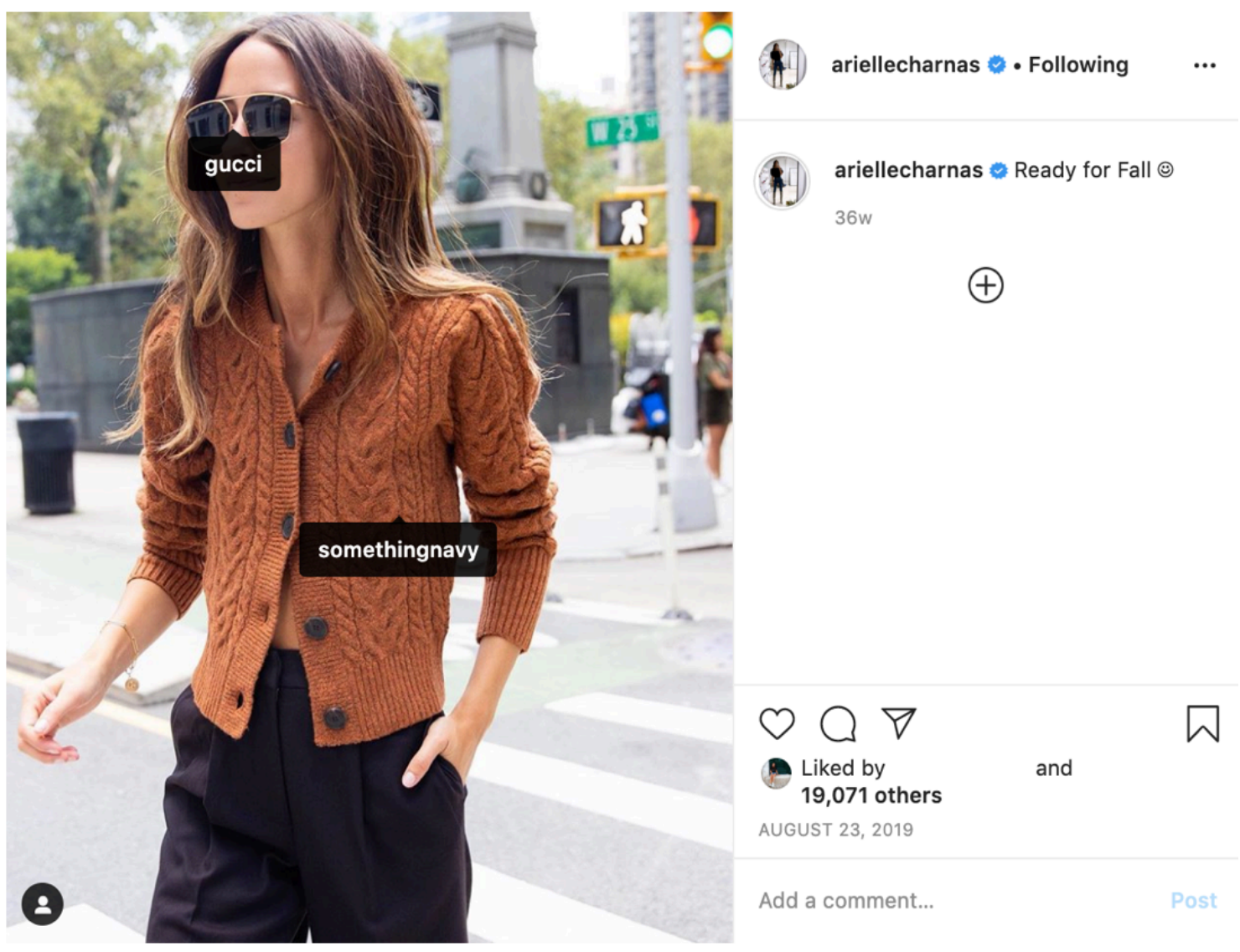


Marwick (2015) proposes that "luxury Instagram accounts function as catalogs of what many young people dream of having and the lifestyle they dream of living” (p. 155). Everything from the Something Navy line is under \$200, and Figure 8 presents Arielle's strategy of pairing those pieces with other far more expensive luxury products that she owns (Messer, 2018, p. 1). Arielle exemplifies opulence, and if she sports her own Something Navy pieces, then her followers that admire her lifestyle may view Something Navy as a luxury brand because of the associations to luxury that Arielle embodies.

Another common influencer practice Arielle exhibits in her Instagram strategy is the technique of creating her own hashtags related to Something Navy. Abidin (2016) explores advertorial campaigns on Instagram, specifically the \#OOTD which is a "genre of posts popular on social media in which users share photographs modelling the clothes they wear" (p. 7). However, instead of using \#OOTD on her posts, Arielle created her own version of that hashtag which she calls the \#snmirromoment, or the "something navy mirror moment". She uses this hashtag when she posts a mirror selfie showcasing her outfit of the day. Arielle created a second hashtag, \#totheSNHQ, which she posts at the end of her Instagram's where she is posing in her outfit walking to her office, which she named the Something Navy headquarters. She only uses personal hashtags within her posts $8 \%$ of the time, as she uses the \#snmirrormoment hashtag four times and the \#totheSNHQ hashtag twice throughout the sampled posts. Not only does Arielle personalize this post of her outfit as displayed in Figure 9 by using her own hashtag, but she also uses the technique of openness. 


\section{Figure 9}

\#snmirrormoment
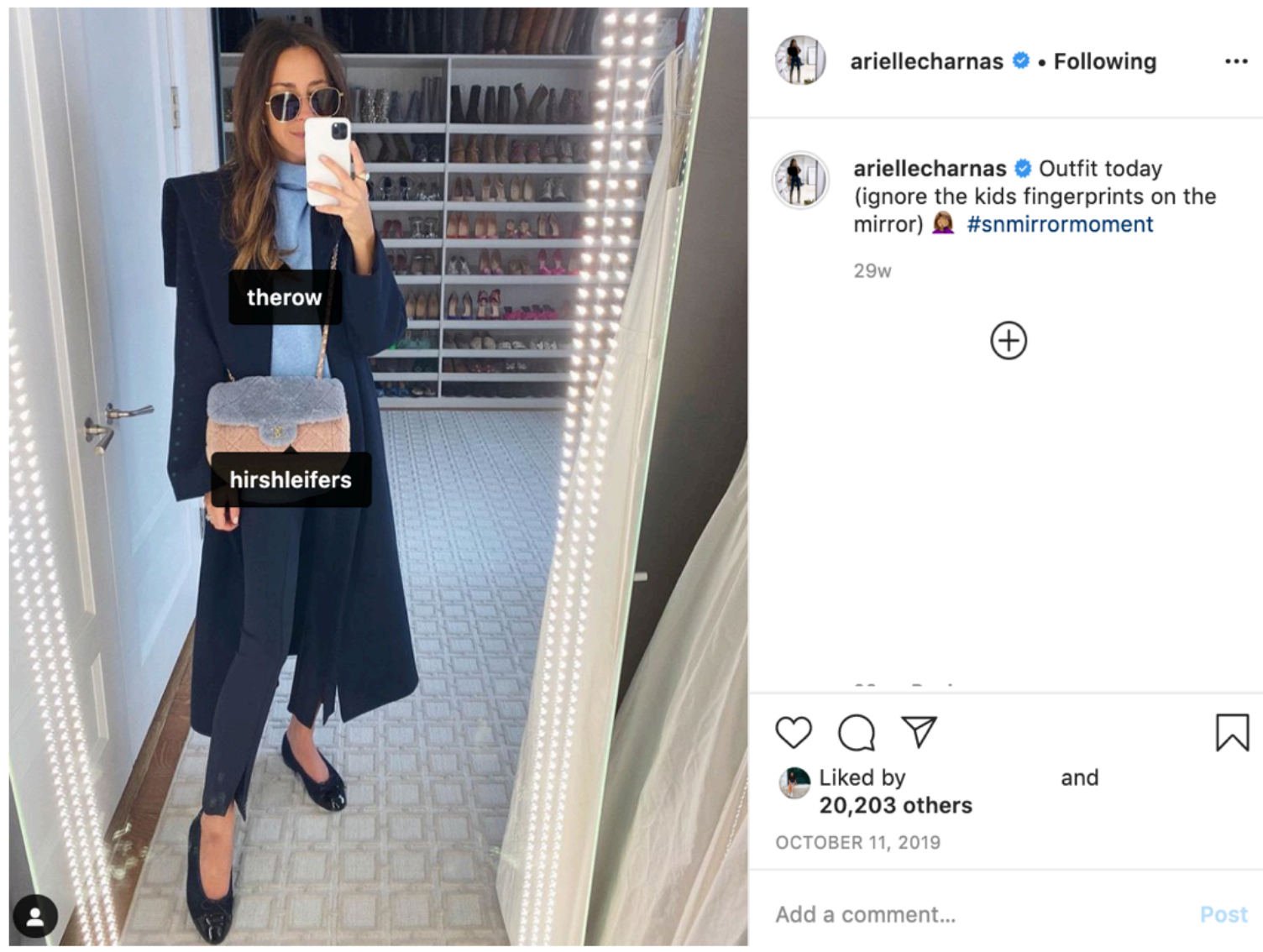

Her use of openness is exhibited in her caption by directing her followers to look at her kids fingerprints in the bottom left corner of her Instagram, showing them that her kids made her mirror filthy, and even she cannot get a perfect mirror selfie. Instagram is a software "designed for personal visual display", and Marwick (2015) advises that this feature "further encourages replicating such imagery" (p. 157). As a result, the hashtags Arielle created are a form of selfpromotion as well, because her followers can post their own Instagram's of their outfits using the \#snmirrormoment hashtag, and that in turn brings more attention to the Something Navy brand. 


\section{Conclusion}

After conducting a detailed analysis, it is clear that perceived interactivity and openness were Arielle's most used parasocial interaction techniques, and there are two prominent patterns that are recognizable in Arielle's posting method. Firstly, the strategy of using perceived interactivity while promoting Something Navy. It is evident that Arielle makes an effort to address her followers both directly and indirectly to make them feel included in the success of Something Navy's evolution. Next, the pairing of the parasocial interaction technique of openness to posts that included Arielle's children and family members was a pattern she used continuously throughout the sampled time frame. As mentioned in the findings and discussion section, $80 \%$ Arielle's most highly engaged with posts included her family, and this evidence could suggest that she knows that her followers are intrigued by viewing the more intimate aspects of her life. Additionally, this supports the proposition that "openness should increase feelings of parasocial interaction" and that "the act of revealing information to a viewer should build intimacy and trust" (Labrecque, 2014, p. 136).

Starting on Friday March $27^{\text {th }}, 2020$, Arielle was inactive for four weeks on her Instagram, which was the longest pause from social media she took in the selected time frame. When she returned back to Instagram on April $24^{\text {th }}, 2020$, her first Instagram back was a picture of her with her two daughters sitting on their bed in casual clothes. This post got 84,500 likes and 8333 comments. The numbers of likes and comments are drastically higher than anything she has ever gotten before. Arielle received double the amount of likes on this post than any other Instagram from the sampled time frame, and about 2000 more comments than her second most commented on post. Pittman and Reich's (2016) findings of their study on social media and loneliness indicate, that the more image-based social media platforms one uses, "the happier, 
more satisfied with life, and less lonely he or she is likely to perceive being" (p. 164). The overwhelming response to Arielle's return to Instagram confirms Labrecque's (2014) statement that interactivity and openness in communication "posit the fostering of parasocial interaction" (p. 136). Furthermore, the enormous reaction welcoming Arielle back to Instagram could possibly suggest that her constant use of interactivity with her followers and her openness were successful in "[enhancing] increased attention" to her platform (Labrecque, 2014, p. 136).

\section{Limitations}

The sample selected for the scope of this research paper was fairly small. Although each post was representative of the type of content Arielle posts on a daily basis, analyzing only one post a week may not be enough data to truly assess the strategies she uses to connect with her followers because she is extremely active on this platform every day. The sample did not include days where she launched and promoted new Something Navy products or significant partnerships and evaluating all those moments may be essential in discovering her patterns of posting on Instagram. Additionally, Arielle constantly uploads images and videos to her Instagram story, which are essentially posts that disappear after 24 hours, and for the realm of this paper her stories were not looked at. Another important limitation to note is that no comments were analyzed. Examining the way Arielle's followers respond and react to her Instagram posts could be essential in discovering the relationship they feel they have with her, which could be revealed in the way they communicate back to her in the comments section. This paper looked at the way influencers may strategically post certain content and communicate with their followers in a way that persuades them to continue to follow their lifestyle on a daily basis. It would be interesting to conduct more research solely on her followers' responses to her Instagram's. This would reveal if they feel a personal connection to her which could asses if a 
parasocial relationship was actually created, and dive deeper into discovering their motives for following her. 


\section{Appendix A- Figures}

\section{Figure 2}

\section{Directly Engaging Followers and Something Navy Promotion}

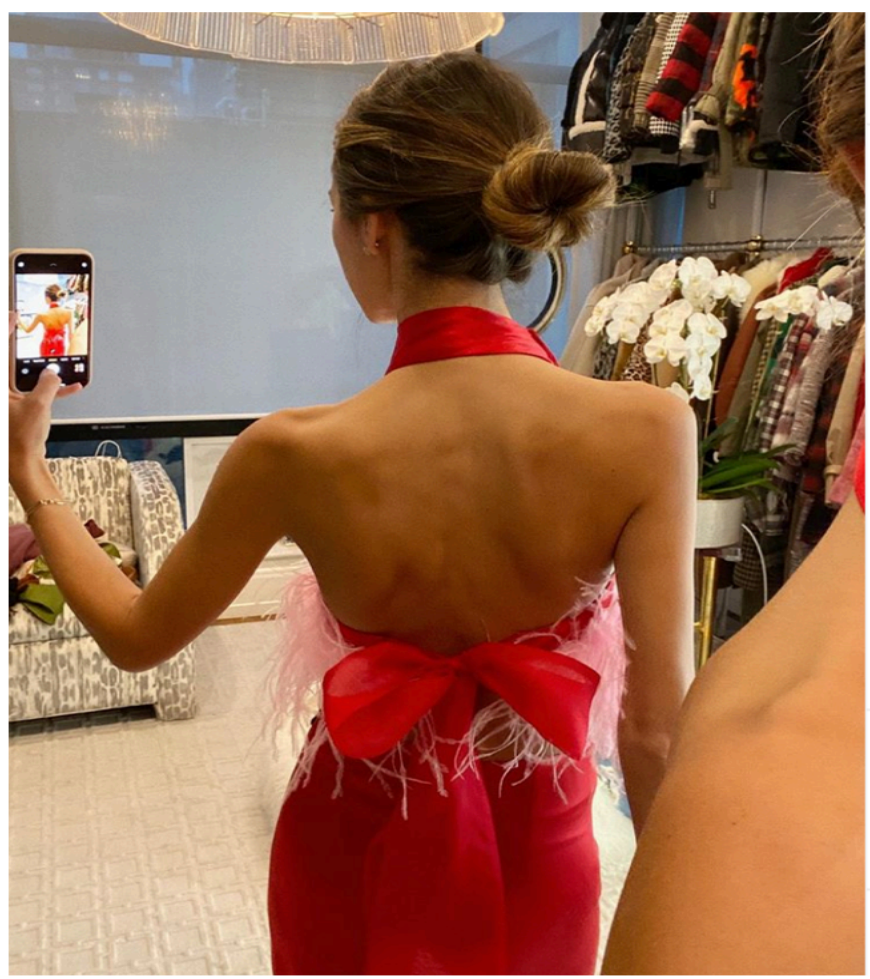

(4) ariellecharnas * Following

(4)

ariellecharnas $*$ Thank you all for helping me design this piece to wear this weekend. This is just a little sneak peek but if you guys see it tomorrow and love it, we will put it into production! l'd love to make it in a bunch of colors (and definitely white for all the brides to be out there)! Stay tuned. @somethingnavy $19 w$

†

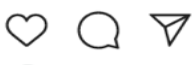

- Liked by 29,159 others and DECEMBER 13, 2019

\section{Figure 4}

\section{Daughter in Bedroom}
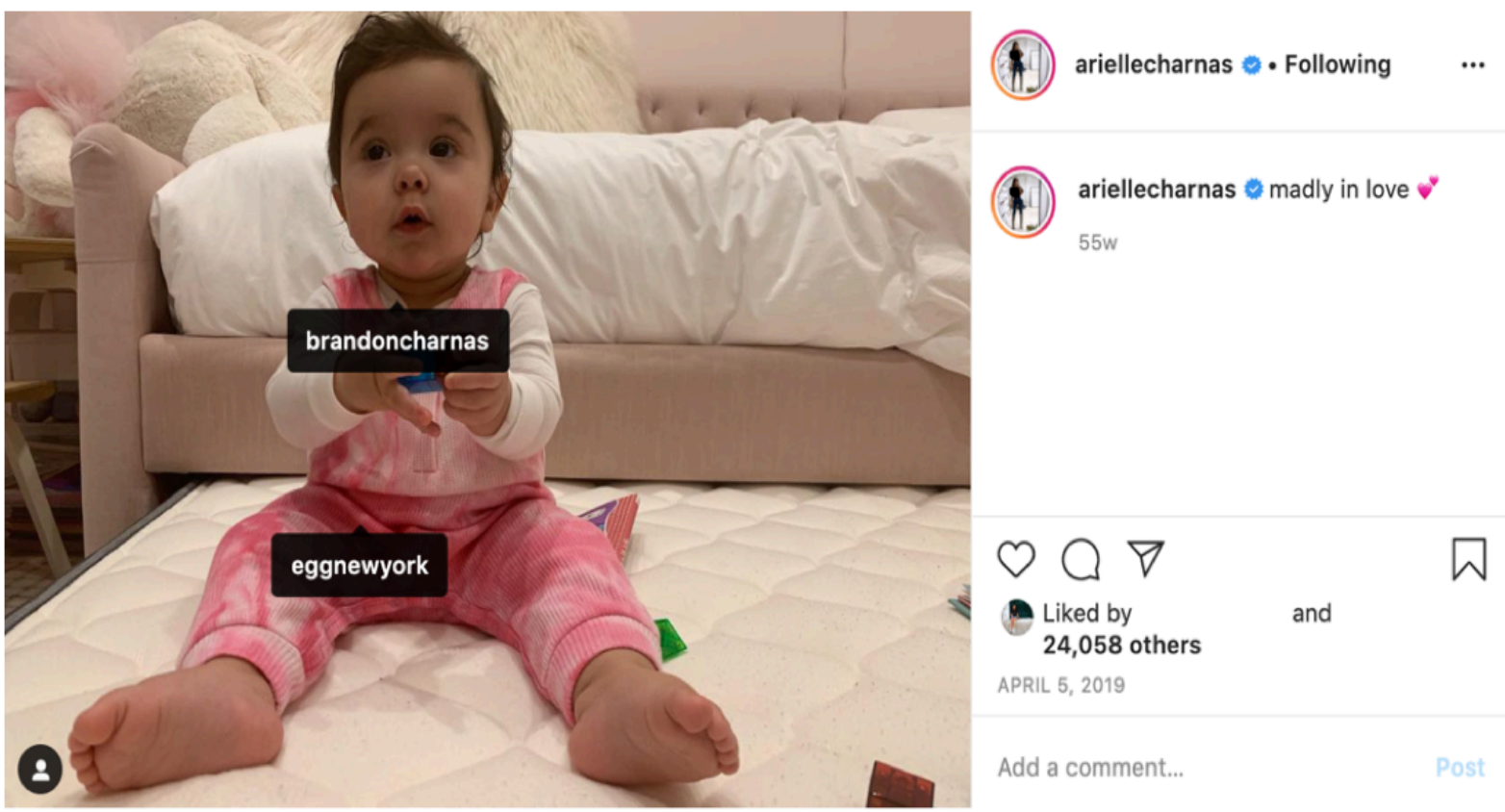
Figure 5

Selfie in the Dark with her Baby
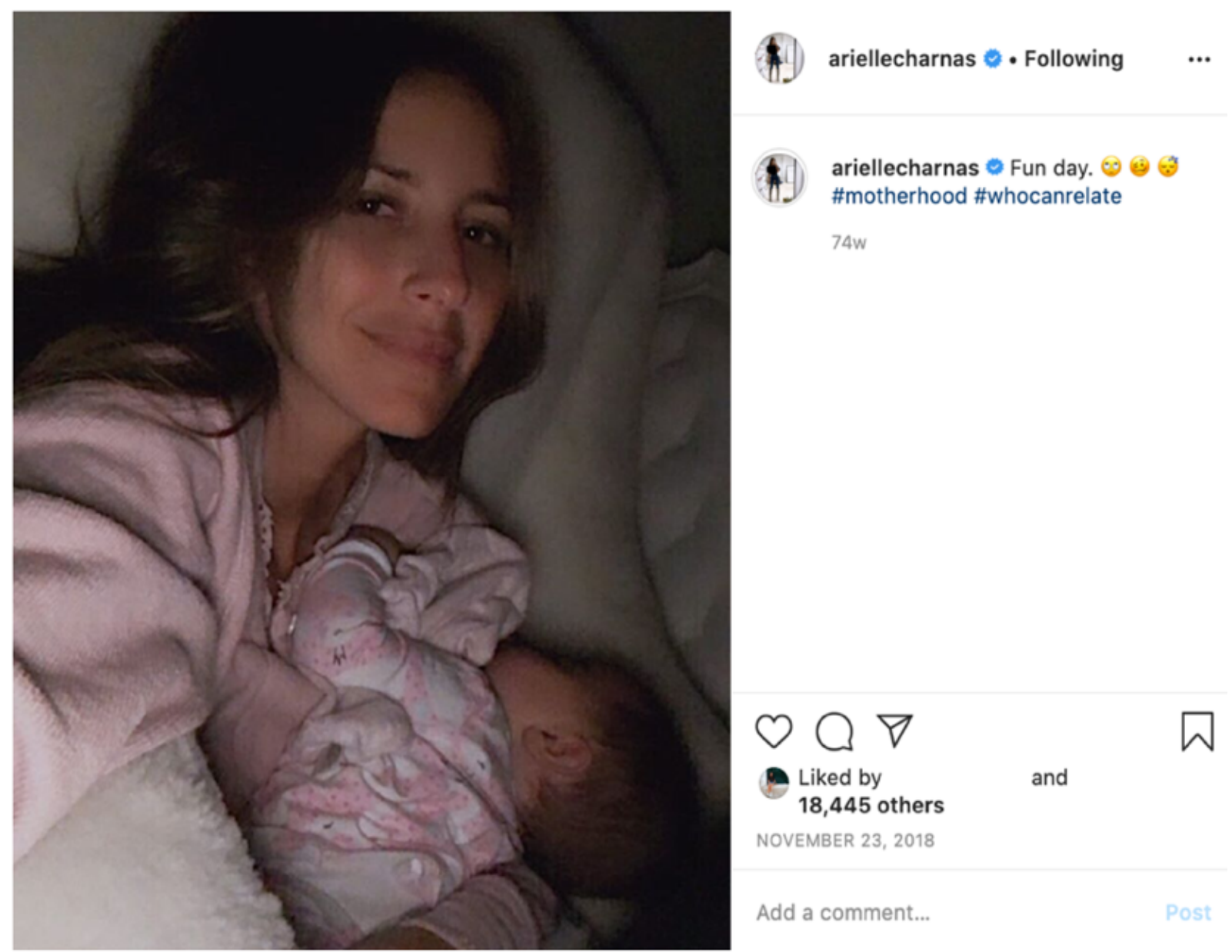


\section{Appendix B- Title, Date of Post, Likes and Comments}

Number of Post

(Year, Month, \# of

post in Month)

\begin{tabular}{|c|c|c|c|c|c|}
\hline & $\begin{array}{l}\text { Date (Day of } \\
\text { Week=Friday) }\end{array}$ & Likes & Comments & Video & Views \\
\hline 1.18 .09 .1 & September 212018 & $20.7 \mathrm{~K}$ & 244 & & \\
\hline 4.18.10.2 & October 122018 & $42.6 \mathrm{~K}$ & 647 & & \\
\hline 8.18 .11 .2 & November 92018 & $16.6 \mathrm{~K}$ & 294 & & \\
\hline 9.18 .11 .3 & November 232018 & $18.4 \mathrm{~K}$ & 125 & & \\
\hline 12.18.12.2 & December 142018 & $28.7 \mathrm{~K}$ & 200 & & \\
\hline 27.19.3.5 & March 292019 & $21.4 \mathrm{~K}$ & 252 & & \\
\hline 45.19 .8 .3 & August 162019 & $29.7 \mathrm{~K}$ & 393 & & \\
\hline 60.19 .12 .2 & December 132019 & $29.1 \mathrm{~K}$ & 191 & & \\
\hline 64.20 .1 .2 & January 102020 & $40.5 \mathrm{~K}$ & 962 & Yes & 352610 \\
\hline
\end{tabular}




\section{References}

Abidin, C. (2016). Visibility labour: engaging with influencers' fashion brands and \#OOTD advertorial campaigns on Instagram. Media International Australia, 161(1), 86-100. https://doi.org/10.1177/1329878X16665177

Auter, P. J. (1992). Tv that talks back: An experimental validation of parasocial interaction scale. Journal of Broadcasting \& Electronic Media, 36(2), 173-182. https://doi.org/10.1080/08838159209364165

Baym, Nancy K. (2015). Personal connections in the digital age (2nd Ed.). Cambridge, UK: Polity.

Berryman, R., \& Kavka, M. (2017). 'I guess a lot of people see me as a big sister or a friend': the role of intimacy in the celebrification of beauty vloggers. Journal of Gender Studies, 26(3), 307-320. https://doi.org/10.1080/09589236.2017.1288611

Boerman, C. S. The effects of the standardized instagram disclosure for micro- and mesoinfluencers, Computers in Human Behaviour, 103, 199-207. https://doi.org/10.1016/j.chb.2019.09.015

Brunner, J. (2007, September 9). Billionaire playground, vacation spots where the filthy rich (of the Forbes 400) hide out. NBC News. http://www.nbcnews.com/id/20891277/ns/travel$\underline{\text { luxury travel/t/billionaire-playgrounds/\#.XvJxhWpKjox }}$

Bryman, A., \& Bell, E. A. (2016). Social research methods. Don Mills, Ontario, Canada: OUP Canada.

Cauberghe, V., Hudders, L., \& and De Veirman, M. (2017). Marketing through instagram influencers: the impact of number of followers and product divergence on brand attitude. 
International Journal of Advertising, 36(5), 798-828.

https://doi.org/10.1080/02650487.2017.1348035

Chen, C.P. (2016). Forming digital self and parasocial relationships on YouTube. Journal of Consumer Culture, 16(1), 232-254. https://doi.org/10.1177/1469540514521081

Childers, C. C., Lemon, L, \& Holy M. G. (2019). \#Sponsored \#Ad: agency perspective on influencer marketing campaigns. Journal of Current Issues \& Research in Advertising, 40(3), 258-274. https://doi.org/10.1080/10641734.2018.1521113

Curotto, M. (2018, December 13). Something Navy's Arielle Charnas Is More Successful Than Ever-But at What Price? Observer. https://observer.com/2018/12/something-navy-stararielle-charnas-launching-nordstrom-holiday-line/

Daniel, E. S., Jackson, E. C. C., \& Westerman, D. K. (2018). The influence of social media influencers: understanding online vaping communities and parasocial interaction through the lens of taylor's six-Segment strategy wheel. Journal of Interactive Advertising, 18(2), 96-109. https://doi.org/10.1080/15252019.2018.1488637

Dibble, J.L., Hartmann, T., Rosaen, S.F. (2016). Parasocial interaction and parasocial relationship: Conceptual clarification and a critical assessment of measures. Human Communication Research, 42(1), 21-44. https://doi.org/10.1111/hcre.12063

Freberg, K., Graham, K., McGaughey, K., \& Freberg, L. A. (2011). Who are the social media influencers? A study of public perceptions of personality. Public Relations Review, 37(1), 90-92. https://doi.org/10.1016/j.pubrev.2010.11.001

Goffman, E. (1956). The presentation of self in everyday life. University of Edinburgh Social Sciences Research Centre. 
Hearn, A., \& Schoenhoff, S. (2015). From celebrity to influencer: Tracing the diffusion of celebrity value across the data stream. In P. D. Marshall \& S. Redmond (Eds.), $A$ Companion to Celebrity (pp. 194-212) John Wiley \& Sons, Inc. https://doi.org/10.1002/9781118475089.ch11

Horton, D., \& Wohl, R. R. (1956). Mass communication and para-social interaction. Psychiatry, 19(3), 215-229.

Hsieh, H.-F., \& Shannon, S. E. (2005). Three approaches to qualitative content analysis. Qualitative Health Research, 15(9), 1277-1288. https://doi.org/10.1177/1049732305276687

Izon, J. (2019, June 19). Go Inside Style Guru Arielle Charnas's Inspired New York Apartment. Architectural Digest. https://www.architecturaldigest.com/story/arielle-charnas-nychome

Messer, L. (2018, September 24). 12 must-have pieces from Something Navy's new line at Nordstrom. Good Morning America. https://www.goodmorningamerica.com/shop/story/12-pieces-navys-nordstrom-line$\underline{57996629}$

Ki, C. W. 'C., \& Kim, Y. K. (2019). The mechanism by which social media influencers persuade consumers: the role of consumers' desire to mimic. Psychology \& Marketing, 36(10), 905-922. https://doi.org/10.1002/mar.21244

Labrecque, L. I. (2014). Fostering consumer-brand relationships in social media environments: the role of parasocial interaction. Journal of Interactive Marketing, 28(2), 134-148. https://doi.org/10.1016/j.intmar.2013.12.003 
Lee, J. E., \& Watkins, B. (2016). YouTube vloggers' influence on consumer luxury brand perceptions and intentions. Journal of Business Research, 69(12), 5753-5760. https://doi.org/10.1016/j.jbusres.2016.04.171

Marwick, A. E. (2015) Instafame: luxury selfies in the attention economy. Public Culture, 27(1), 137-160. https://doi.org/10.1215/08992363-2798379

Marwick, A., \& Boyd, D. (2011) To see and be seen: celebrity practice on twitter. Convergence, 17(2), 139-158. https://doi.org/10.1177/1354856510394539

Perse, E. M., \& Rubin, R. R. (1989). Attribution in social and para-social relationships. Communication Research, 16(1), 59-77. https://doi.org/10.1177/009365089016001003

Sheldon, P., \& Bryant, K. (2016). Instagram: Motives for its use and relationship to narcissism and contextual age. Computers in Human Behavior, 58, 89-97. https://doi.org/10.1016/j.chb.2015.12.059

Sokolova, K., \& Kefi, H. (2019). Instagram and YouTube bloggers promote it, why should I buy? How credibility and parasocial interaction influence purchase intentions. Journal of Retailing and Consumer Services, 53, 1-9. https://doi.org/10.1016/j.jretconser.2019.01.011

Something Navy (2020) About. https://somethingnavy.com/about/

Something Navy (2020) My Story Part One. https://somethingnavy.com/story-part-one/

Stephens, D. L., R. P. Hill \& Bergman, K. (1996) Enhancing the consumer-product relationship: Lessons from the QVC home shopping channel. Journal of Business Research, 37, 193200. https://doi.org/10.1016/S0148-2963(96)00069-0 
Stern, B., Russel, C.A., \& Russel D.W. (2007). Hidden persuasions in soap operas: damaged heroines and negative consumer effects. International Journal of Advertising, 26(1), 936. https://doi.org/10.1080/02650487.2007.11072994

Stever, G. S., \& Lawson, K. (2013). Twitter as a way for celebrities to communicate with fans: Implications for the study of para-social interaction. North American Journal of Psychology, 15(2), 339-354.

Strugatz, R. (2016, August 10). Bloggers and digital influencers are reshaping the fashion and beauty landscape. Los Angeles Times. https://www.latimes.com/fashion/la-ig-bloggers20160809-snap-story.html 